\title{
Impact of Front Range sources on reactive nitrogen concentrations and deposition in Rocky Mountain National Park
}

Katherine B. Benedict Corresp., 1 Anthony J Prenni ${ }^{2}$ Amy P Sullivan ${ }^{1}$ Ashley R Evanoski-Cole ${ }^{1,3}$, Emily V Fischer $^{1}$, Sara Callahan ${ }^{1}$, Barkley C Sive ${ }^{2}$, Yong Zhou ${ }^{1}{ }^{\text {, Bret A Schichtel }}{ }^{4}$ ， Jeffrey L Collett Jr. ${ }^{1}$

${ }^{1}$ Department of Atmospheric Science, Colorado State University, Fort Collins, Colorado, United States

2 Air Resources Division, National Park Service, Lakewood, CO, US

3 now at Department of Chemistry, St. Bonaventure University, St. Bonaventure, NY, United States

${ }^{4}$ Air Resources Division, National Park Service, Fort Collins, CO, US

Corresponding Author: Katherine B. Benedict

Email address: katherine.benedict@colostate.edu

Human influenced atmospheric reactive nitrogen (RN) is impacting ecosystems in Rocky Mountain National Park (ROMO). Due to ROMO's protected status as a Class 1 area, these changes are concerning and improving our understanding of the contributions of different types of RN and their sources is important for reducing impacts in ROMO. In July-August 2014 the most comprehensive measurements (to date) of RN were made in ROMO during the Front Range Air Pollution and Photochemistry Éxperiment (FRAPPÉ). Measurements included peroxyacetyl nitrate (PAN), $\mathrm{C}_{1}-\mathrm{C}_{5}$ alkyl nitrates, and high-time resolution $\mathrm{NO}_{\mathrm{x}}, \mathrm{NO}_{\mathrm{y}}$, and ammonia. A limited set of measurements was extended through October. Co-located measurements of a suite of volatile organic compounds provide information on source types impacting ROMO. Specifically, we use ethane as a tracer of oil and gas operations and tetrachloroethylene $\left(\mathrm{C}_{2} \mathrm{Cl}_{4}\right)$ as an urban tracer to investigate their relationship with $\mathrm{RN}$ species and transport patterns. Results of this analysis suggest elevated RN concentrations are associated with emissions from oil and gas operations, which are frequently co-located with agricultural production and livestock feeding areas in the region, and from urban areas. There also are periods where reactive nitrogen at ROMO is impacted by long-range transport. We present an atmospheric RN budget and a nitrogen deposition budget with dry and wet components. Total deposition for the period (7/1-9/30) was estimated at $1.58 \mathrm{~kg} \mathrm{~N} / \mathrm{ha}$, with $87 \%$ from wet deposition during this period of above average precipitation. Ammonium wet deposition was the dominant contributor to total nitrogen deposition followed by nitrate wet deposition and total dry deposition. Ammonia was estimated to be the largest contributor to dry deposition followed by nitric acid and PAN (other species included alkyl nitrates, ammonium and nitrate). All three species are challenging to measure routinely, especially at high time resolution. 


\section{Impact of Front Range Sources on Reactive Nitrogen Concentrations and Deposition in Rocky Mountain National Park}

1

Katherine B. Benedict ${ }^{1}$, Anthony J. Prenni ${ }^{2}$, Amy P. Sullivan ${ }^{1}$, Ashley R Evanoski-Cole ${ }^{1,3}$, Emily V. Fischer ${ }^{1}$, Sara Callahan ${ }^{1}$, Barkley C. Sive ${ }^{2}$, Yong Zhou ${ }^{1}$, Bret A Schichtel ${ }^{4}$, Jeffrey L. Collett, Jr. ${ }^{1}$

${ }^{1}$ Department of Atmospheric Science, Colorado State University, Fort Collins, CO, USA

${ }^{2}$ National Park Service, Air Resources Division, Lakewood, CO, USA

${ }^{3}$ now at Department of Chemistry, St. Bonaventure University, St. Bonaventure, NY, USA

${ }^{4}$ National Park Service, Air Resources Division, Fort Collins, CO, USA 


\section{Abstract}

24 Human influenced atmospheric reactive nitrogen $(\mathrm{RN})$ is impacting ecosystems in Rocky

25 Mountain National Park (ROMO). Due to ROMO's protected status as a Class 1 area, these

26 changes are concerning and improving our understanding of the contributions of different types

27 of RN and their sources is important for reducing impacts in ROMO. In July-August 2014 the

28 most comprehensive measurements (to date) of RN were made in ROMO during the Front Range

29 Air Pollution and Photochemistry Éxperiment (FRAPPÉ). Measurements included peroxyacetyl

30 nitrate $(\mathrm{PAN}), \mathrm{C}_{1}-\mathrm{C}_{5}$ alkyl nitrates, and high-time resolution $\mathrm{NO}_{\mathrm{x}}, \mathrm{NO}_{\mathrm{y}}$, and ammonia. A limited

31 set of measurements was extended through October. Co-located measurements of a suite of

32 volatile organic compounds provide information on source types impacting ROMO.

33 Specifically, we use ethane as a tracer of oil and gas operations and tetrachloroethylene $\left(\mathrm{C}_{2} \mathrm{Cl}_{4}\right)$

34 as an urban tracer to investigate their relationship with RN species and transport patterns.

35 Results of this analysis suggest elevated RN concentrations are associated with emissions from

36 oil and gas operations, which are frequently co-located with agricultural production and livestock

37 feeding areas in the region, and from urban areas. There also are periods where reactive nitrogen

38 at ROMO is impacted by long-range transport. We present an atmospheric RN budget and a

39 nitrogen deposition budget with dry and wet components. Total deposition for the period (7/1-

40 9/30) was estimated at $1.58 \mathrm{~kg} \mathrm{~N} / \mathrm{ha}$, with $87 \%$ from wet deposition during this period of above

41 average precipitation. Ammonium wet deposition was the dominant contributor to total nitrogen

42 deposition followed by nitrate wet deposition and total dry deposition. Ammonia was estimated

43 to be the largest contributor to dry deposition followed by nitric acid and PAN (other species

44 included alkyl nitrates, ammonium and nitrate). All three species are challenging to measure

45 routinely, especially at high time resolution. 


\subsection{Introduction}

The nitrogen cycle has been altered by increasing production of reactive nitrogen $(\mathrm{RN})$ for food production and energy (Galloway et al., 2008). Much of the reactive nitrogen produced ultimately ends up in air and water, potentially contributing to environmental problems (Fenn et al., 1998; Howarth, 2004). Direct leaching from fertilized soils contributes to eutrophication of fresh water. Emissions to the atmosphere can increase ozone and particle formation as well as contribute to elevated nitrogen deposition to land surfaces and water bodies. Elevated nitrogen deposition can alter ecosystems and the services they provide in many regions (Goulding et al., 1998; Fenn et al., 2003; Burns, 2004; Bell et al., 2017) as many ecosystems are nitrogen limited (LeBauer \& Treseder, 2008). Across the globe there has been intense focus on understanding levels of nitrogen deposition and its impacts in particularly sensitive and protected ecosystems.

Over the past several decades, researchers in Europe, the United States, and China have focused on better understanding the interactions and changes in ecosystems that occur as a result of excess reactive nitrogen deposition using long-term networks. An extensive network was established throughout Europe in 2006-2011 to measure ambient RN concentrations, estimate dry deposition and provide a comprehensive data set for regional models (Owen et al., 2011; Flechard et al., 2011). In contrast, work in the United States has focused primarily on wet nitrogen deposition measurements made by the National Atmospheric Deposition Program (NADP) (Lehmann, Bowersox \& Larson, 2005). In China there has not been a long-term national deposition monitoring program; however there has been an effort to implement longterm standardized nitrogen deposition measurements (Liu et al., 2011). 
70 subalpine forests (Baron et al., 1994). The Rocky Mountains are more susceptible to reactive

71 nitrogen deposition than many other areas because nitrogen is not well retained in the local soil

72 and plants. Reduced plant nitrogen demand results from a short growing season, which

73 decreases nitrogen retention. Additionally, the soil types in the area (exposed bedrock, talus,

74 coarse soils) reduce contact time between drainage water and soil (Fenn et al., 1998).

75 Research aimed at improved understanding of nitrogen deposition in ROMO has been

76 ongoing for many years (Bowman \& Steltzer, 1998; Burns, 2003, 2004; Baron et al., 2004;

77 Baron, 2006; Beem et al., 2010; Benedict et al., 2013c,a). Several studies have demonstrated

78 that increased nitrogen deposition has been associated with changes in biological species and

79 ecological processes (Bowman \& Steltzer, 1998; Burns, 2004; Baron, 2006), and a high spatial

80 variability of nitrogen deposition in the region has been observed from national monitoring

81 network data (Burns, 2003; Beem et al., 2010). Measurements characterizing many reactive

82 nitrogen species are routinely collected in the park as part of NADP, the Interagency Monitoring

83 of Protected Visual Environments (IMPROVE) program, the Clean Air Status and Trends

84 Network (CASTNET), and the Ammonia Monitoring Network (AMoN). These networks

85 provide the data needed for tracking progress toward reduction of nitrogen deposition in ROMO,

86 a goal mutually set by the State of Colorado, the US EPA, and the National Park Service

87 (CDPHE, 2017). Special studies like the Rocky Mountain Atmospheric Nitrogen and Sulfur

88 (RoMANS) Studies (Malm et al., 2009) have increased the understanding of the type and

89 frequency of atmospheric transport that plays a role in atmospheric nitrogen inputs into the

90 ecosystems at ROMO as well as the importance of wet organic nitrogen deposition and dry

91 deposition of ammonia $\left(\mathrm{NH}_{3}\right)$ (Beem et al., 2010; Benedict et al., 2013c,a). 
93 conducted July 15 through August 18, 2014. Although the primary goal of FRAPPÉ was to

94 better characterize summertime air quality in the Northern Front Range Metropolitan Area

95 (NFRMA), the extensive suite of measurements collected during FRAPPÉ allowed for

96 determination of the degree to which pollution from NFRMA sources and long-range transport

97 contribute to air quality impacts at ROMO. FRAPPÉ was conducted in parallel with the 2014

98 DISCOVER-AQ (Deriving Information on Surface Conditions from Column and Vertically

99 Resolved Observations Relevant to Air Quality) project in Colorado. Research flights, surface

100 mobile measurements, and stationary ground sites were coordinated to provide a comprehensive

101 picture of the atmospheric processes impacting air quality in the northern Front Range. The

102 majority of operations took place along the Front Range, near the main pollutant sources in the

103 region, although research flights and several ground sites characterized more remote areas to

104 better understand the transport and impact from the source regions.

105 In this manuscript, we describe measurements made during FRAPPÉ from a ground site

106 collocated with routine monitoring measurements at the Rocky Mountain National Park Longs

107 Peak (ROMO-LP) field site. Measurements began July 7, prior to the FRAPPÉ study period, and

108 continued through October 15, well after the campaign ended. These measurements included

109 high time resolution ( 1 min to 1 hour) $\mathrm{NH}_{3}$, nitric oxide (NO), and $\mathrm{NO}_{\mathrm{y}}$ ( (oxidized nitrogen)

110 concentrations, as well as more comprehensive 24-hour gas $\left(\mathrm{NH}_{3}\right.$, nitric acid - $\mathrm{HNO}_{3}$, sulfur

111 dioxide $-\mathrm{SO}_{2}$ ) and particle chemistry (ammonium- $\mathrm{NH}_{4}{ }^{+}$, nitrate- $\mathrm{NO}_{3}{ }^{-}$, sulfate $-\mathrm{SO}_{4}{ }^{2-}$, sodium -

$112 \mathrm{Na}^{+}$, potassium $-\mathrm{K}^{+}$, magnesium $-\mathrm{Mg}^{2+}$, calcium $-\mathrm{Ca}^{2+}$, and chloride $-\mathrm{Cl}^{-}$) measurements.

113 Two gas chromatographs were used to measure select organic nitrogen species including

114 peroxyacetyl nitrate $(\mathrm{PAN})$, methyl nitrate $\left(\mathrm{MeONO}_{2}\right)$, ethyl nitrate $\left(\mathrm{EtONO}_{2}\right)$, i-propyl nitrate 
115 (iPrONO 2$)$, 2-butyl nitrate $\left(2 \mathrm{BuONO}_{2}\right)$, 2-pentyl nitrate $\left(2 \mathrm{PenONO} \mathrm{O}_{2}\right)$, and 3-pentyl nitrate

$\left.116(3 \mathrm{PenONO})_{2}\right)$; as well as volatile organic compound (VOC) tracers for a variety of sources.

117 These measurements were aimed at better understanding the sources that contribute to pollutant

118 concentrations in ROMO, specifically for $\mathrm{RN}$ species. We provide a comprehensive budget for

$119 \mathrm{RN}$ in ROMO during FRAPPÉ, calculate a nitrogen deposition budget, and assess important

120 sources for the primary components of the RN budget.

121

\section{$122 \quad 2.0$ Methods}

123 The measurement site at ROMO (Figure 1) was located south of Estes Park, CO, near the base of

124 Longs Peak. The site $\left(40.2783^{\circ},-105.5457^{\circ} ; 2784 \mathrm{~m} \mathrm{ASL}\right)$ is co-located with IMPROVE

125 (ROMO1) and CASTNet (ROM206/406) national network monitoring sites, and the National

126 Park Service Gaseous Pollutant Monitoring Network (GPMP). Measurements were conducted

127 both in the GPMP shelter and in the National Park Service/Colorado State University Mobile Air

128 Quality Laboratory stationed at the site.

129

130

1312.1 High-time resolution $\mathrm{NH}_{3}$ and $\mathrm{NO}_{y}$

132 High-time resolution $(\sim 5 \mathrm{sec})$ measurements of $\mathrm{NH}_{3}$ were made using a Picarro G1103

133 Analyzer, a cavity ring-down spectroscopy instrument, located in mobile laboratory. The inlet

134 line (Teflon tubing) was located approximately $6 \mathrm{~m}$ above ground level (agl). The entire length

135 of the inlet line was insulated and heated to $40^{\circ} \mathrm{C}$ to minimize wall losses. A filter (Picarro P/N

136 S1021) was placed on the end of the inlet to prevent particles from entering the instrument.

137 Ammonium nitrate captured by the filter likely volatilized on the heated filter during sampling

138 and is a potential source of bias in the $\mathrm{NH}_{3}$ measurement. However, concurrent 24-hr averaged 
139 measurements from an annular denuder/filter-pack sampler (see below) suggest that, assuming

140 that all of the $\mathrm{NH}_{4} \mathrm{NO}_{3}$ sublimates and is measured as $\mathrm{NH}_{3}$, the median bias in the measurements

141 was 7.7\%. A correction was not applied to the final dataset. Calibrations were performed at the

142 beginning and end of the field deployment with a known concentration of ammonia, generated

143 using a calibration gas diluted with a Teledyne Zero Air Generator (Model 701). A phosphorus

144 acid $(10 \% \mathrm{w} / \mathrm{v})$ coated denuder operated in parallel confirmed the supplied $\mathrm{NH}_{3}$ concentration.

145 The mobile lab, which housed the instrument, had an air conditioning failure July 23-30 resulting

146 in conditions that were too hot for proper operation of the Picarro. After A/C was restored, a

147 section of the heated inlet overheated and this problem was not discovered until August 8. Thus

$148 \mathrm{NH}_{3}$ data for the period July 23 - August 9 are omitted from this analysis.

149 CASTNET $\mathrm{NO}_{\mathrm{y}}$ and NO data were downloaded from www.epa.gov/castnet (U.S.

150 Environmental Protection Agency Clean Air Markets Division, 2016a). A Teledyne API

$151 \mathrm{~T} 200 \mathrm{U} / \mathrm{NO}_{\mathrm{y}}$ instrument is operated at the ROMO CASTNET site (ROM206). This instrument

152 measures both $\mathrm{NO}_{\mathrm{y}}$ and $\mathrm{NO}$ by chemiluminescence. $\mathrm{NO}$ is directly measured and $\mathrm{NO}_{\mathrm{y}}$ is

153 converted using a thermal catalytic converter and measured as NO (US EPA, 2017). This method

154 has an uncertainty of $\leq \pm 10 \%$ with the additional caveats that some reduced organic nitrogen

155 compounds may be converted and the conversion of the different $\mathrm{NO}_{\mathrm{y}}$ species is highly

156 temperature dependent (Crosley, 1996; Kondo et al., 1997; Williams et al., 1998). The site is

157 operated in accordance with the Quality Assurance Plan for Procuring, Installing, and Operating

158 NCore Air Monitoring Equipment at CASTNET sites (Amec Foster Wheeler, 2016).

159

1602.2 High-time resolution organic compounds 
An in situ gas chromatography (GC) system was setup in the mobile laboratory located at

162 the ROMO site to measure hourly concentrations of select VOCs. This is a cryogen-free

163 concentration and analysis system consisting of two GCs coupled to 4 columns. A VF-1701

164 (Varian Inc.) was used with an electron capture detector (ECD) for C1-C2 halocarbons and C1-

165 C5 alkylnitrates; a Flame Ionization Detector (FID) was used with the three other columns: CP-

$166 \mathrm{Al}_{2} \mathrm{O}_{3} / \mathrm{Na}_{2} \mathrm{SO}_{4}$ PLOT for detection of $\mathrm{C}_{2}-\mathrm{C}_{7}$ hydrocarbons, VF-1ms for $\mathrm{C}_{6}-\mathrm{C}_{10}$ hydrocarbons and

167 a PoraBond Q column for selected oxygenated VOCs (OVOCs). The system, calibrated daily, is

168 similar to those used in other studies (Sive et al., 2005; Abeleira et al., 2017). The GC was

169 located in the mobile lab, data are unavailable for the July 23-30 period of the A/C failure.

170 Peroxyacetyl nitrate (PAN) was measured at ROMO using a custom gas chromatograph

171 with 15-min time-resolution in the GPMP shelter. For the ROMO 2014 deployment, this custom

172 system was configured to measure PAN, but not its homologues. The instrument operation and

173 calibration are described in Zaragoza et al (2017). Briefly, the system used a ThermQuest ECD

174 held at $50^{\circ} \mathrm{C}$ and calibrations were performed regularly throughout the campaign using a

175 photolysis cell to generate PAN with accurately measured flows of acetone in ultra high purity

176 zero air and NO in nitrogen (Scott-Marrin Cylinder Numbers: CB09819 and CB11156).

$1782.324-h o u r$ inorganic gases and particles

179 24-hour inorganic gas and $\mathrm{PM}_{2.5}$ particle chemistry was measured using URG annular

180 denuders and filter-packs (URG Corporation, Chapel Hill, NC), replaced daily at 9:00 MDT,

181 with a nominal volumetric flow of $10 \mathrm{~L} / \mathrm{min}$. These samplers were located outside the mobile

182 laboratory at the ROMO site. Details on sample extraction and analysis can be found in previous

183 work (Beem et al., 2010; Benedict et al., 2013b,c). The collected samples were analyzed to 
184 determine the concentrations of gas phase $\mathrm{NH}_{3}$ and $\mathrm{HNO}_{3}$ and particle phase $\mathrm{NH}_{4}{ }^{+}, \mathrm{NO}_{3}{ }^{-}, \mathrm{SO}_{4}{ }^{2-}$,

$185 \mathrm{~K}^{+}, \mathrm{Na}^{+}, \mathrm{Cl}^{-}, \mathrm{Mg}^{2+}$, and $\mathrm{Ca}^{2+}$.

186

187 2.4 Wet Deposition

188 Precipitation samples were collected using an automated NCON Systems (Arnoldsville,

189 GA, USA) ADS/NTN Atmospheric Precipitation Sampler. Sample buckets were changed every

1902 to 3 days depending on the site visit schedule. Sample buckets were cleaned with deionized

191 water, shaken to remove water, covered with Al foil, and allowed to dry. Blanks were taken by

192 pipetting $30 \mathrm{~mL}$ of high-purity deionized water into the bucket. Each bucket was weighed prior

193 to installation in the field and upon returning to the lab to determine the total sample volume

194 collected. Sample $\mathrm{pH}$ was measured after returning to the lab using a combination $\mathrm{pH}$ electrode

195 and the remaining sample was frozen until analysis. Samples were analyzed for ionic

196 composition $\left(\mathrm{NH}_{4}^{+}, \mathrm{NO}_{3}^{-}, \mathrm{SO}_{4}^{2-}, \mathrm{Na}^{+}, \mathrm{K}^{+}, \mathrm{Mg}^{2+}, \mathrm{Ca}^{2+}\right.$, and $\left.\mathrm{Cl}^{-}\right)$using ion chromatography

197 (Dionex) with conductivity detection and for total nitrogen by high temperature catalyzed

198 combustion with chemiluminescent analysis of NO using a Shimadzu TOC $\mathrm{V}_{\mathrm{CSH}}+\mathrm{TNM}-1$ total

199 organic carbon analyzer with total nitrogen module (Benedict et al., 2013a).

200

201

\subsection{Results and Discussion}

202

\subsection{Overview of sampling period}

203

A timeline of the FRAPPÉ period is shown in Figure 2 for the nitrogen species

204

measured at high-time resolution, key tracer species, wind direction and precipitation. From the

wind direction data, we can see that consecutive days of upslope flow (shaded region, $90-180^{\circ}$ )

from the Front Range, when winds are from the southeast, mainly occurred at the end of July and 
207 beginning of August and then again mid-month in August. We note that because the site is

208 located in a valley, winds are channeled primarily in two directions (Figure 3): from the

209 southeast (upslope flow from the Colorado Front Range and northeast Colorado) and from the

210 northwest (from less developed areas west of the Continental Divide). From previous work we

211 know transport from the Front Range is an important source of nitrogen to ROMO (Beem et al.,

212 2010; Benedict et al., 2013c); during periods of upslope flow in 2014 we also observe increases

213 in the Front Range tracers and reactive nitrogen species. The pollution rose for PAN is shown as

214 an example (Figure 3) of the higher concentrations of reactive nitrogen species associated with

215 upslope flow. This pattern of higher concentrations being associated with southeast (upslope)

216 flow is similar for all of the reactive nitrogen species measured. On August 11 and 12 there were

217 strong upslope winds and $\mathrm{NH}_{3}$ was the highest observed during the FRAPPE study period.

218 Others have suggested a fire influence in the Front Range during the August 11 and 12 period

219 (Dingle et al., 2016), which may also contribute to reactive nitrogen concentrations (Benedict et

220 al., 2017). Other upslope periods (e.g., July 22) show stronger signals in tracer species

221 compared to $\mathrm{NH}_{3}$. Throughout the study period, there appear to be strong correlations between

222 the peak concentrations of $\mathrm{PAN}, \mathrm{R}-\mathrm{ONO}_{2}$, ethane, and $\mathrm{C}_{2} \mathrm{Cl}_{4}$, suggesting similar sources and/or

223 source regions, and $\mathrm{NO}_{\mathrm{y}}$ concentration timelines share similarities to PAN. Unfortunately, due

224 to air conditioner failures, limited data were collected for portions of the study period.

225 To improve our understanding of the sources and relationships between compounds, we

226 next examine the diurnal cycles of several key N species (Figure 4). Most of the species have a

227 peak later in the day, likely associated with radiatively driven upslope transport, while there is an

228 early peak in ammonia which is more likely to be associated with bi-directional exchange and

229 the role of dew (Wentworth et al., 2016). An early morning peak in ammonia has been observed 
230 at other sites, including in Grand Teton National Park (Prenni et al., 2014), suggesting this may

231 be a common occurrence. The early morning high concentrations of ammonia reflect local

232 environmental effects (volatilization from evaporating dew) that strongly alter morning ammonia

233 concentrations. There is no clear early morning peak of $\mathrm{NH}_{3}$ observed in the August diurnal

234 averages shown in Figure 4, perhaps due to drier conditions. Earlier in the study (July) there

235 were several large early morning peaks that are likely related to dew evaporation. To eliminate

236 this factor from our source analysis, the morning (6 AM - $10 \mathrm{AM})$ ammonia data were removed

237 from the remainder of the analyses as any local factors that cause high $\mathrm{NH}_{3}$ concentration would

238 confound any interpretation of correlations with other species. $\mathrm{NO}_{\mathrm{y}}$ peaks early, between 6AM

239 and 9AM, likely related to local morning traffic and then peaks again mid-afternoon through the

240 evening with a lot of variability in when the highest late-day concentration is observed. The

241 alkyl nitrates have the latest peak in concentration and are most similar to the diurnal cycles of

242 the two tracer species $\left(\mathrm{C}_{2} \mathrm{Cl}_{4}\right.$ and ethane). Concentrations of total $\mathrm{R}-\mathrm{ONO}_{2}$ are consistently low

243 from the early morning (2 AM) through noon with the highest concentrations observed between

2445 PM and 11 PM. On average the increases in PAN begin around 7 AM, likely associated with

245 sunrise and the initiation of photochemical reactions. PAN slowly increases throughout the day

246 with its average peak concentration occurring around 6 PM before concentrations begin to

247 decrease overnight.

248

2493.2 Atmospheric Reactive Nitrogen Budget

250 The 2014 period of intensive measurements provided an opportunity to examine the

251 contribution of individual nitrogen compounds to the total atmospheric reactive nitrogen budget. 
252 For the FRAPPÉ period (July 16 - August 18), $\mathrm{NO}_{\mathrm{y}}$ species were the most abundant,

253 contributing $67 \%$ to the total RN budget (Figure 5).

254 Based on our speciated measurements, $\mathrm{NO}_{\mathrm{y}}$ was partitioned as follows: $24 \%$ as PAN, $7 \%$

255 as $\mathrm{NO}, 4 \%$ as alkyl nitrates, and $11 \%$ as $\mathrm{HNO}_{3}$ and $\mathrm{NO}_{3}^{-}$. We estimate that the remaining $54 \%$

256 was $\mathrm{NO}_{2}$ and other unmeasured oxidized nitrogen species $\left(\mathrm{NO}_{\mathrm{z}}\right)$. We note that we cannot

257 separate $\mathrm{NO}_{2}$ concentrations from other $\mathrm{NO}_{z}$ contributions using the chemiluminescence

258 instrument and converter system employed during FRAPPÉ. Other potential contributors to the

$259 \mathrm{NO}_{\mathrm{z}}$ fraction include other organo-nitrogen compounds like hydroxynitrates, isoprene nitrates,

260 and peroxyacyl nitrates other than PAN, but their importance is uncertain and is likely to vary

261 spatially and temporally (Parrish et al., 1993; Thornberry et al., 2001; Day et al., 2003). At night

$262 \mathrm{NO}_{3}{ }^{\bullet}$ and $\mathrm{N}_{2} \mathrm{O}_{5}$ could be important contributors to $\mathrm{NO}_{\mathrm{y}}$ but in the presence of isoprene and

263 unsaturated alkenes are likely to react, photolyze to $\mathrm{NO}_{2}$ at sunrise, or, in the case of $\mathrm{N}_{2} \mathrm{O}_{5}$,

264 undergo hydrolysis on aerosols to form particulate $\mathrm{NO}_{3}^{-}$(Brown S. S. et al., 2004; Brown et al.,

265 2006). Previous measurements in Boulder and Denver show large temporal variability with

266 concentration ranging from below detection to $100 \mathrm{pptv}$ for $\mathrm{NO}_{3}{ }^{\bullet}$ and below detection to 3 ppbv

267 for $\mathrm{N}_{2} \mathrm{O}_{5}$ (Brown \& Stutz, 2012). While the specific contribution to nitrogen deposition is

268 unknown for these species, they are expected to be captured in the $\mathrm{NO}_{\mathrm{y}}$ measurement.

269 A subset of the RN species have been measured at ROMO in previous years. Summary

270 data from these measurements are given in Table 1. The overall partitioning between reduced

271 and oxidized reactive nitrogen (i.e. leftmost column of Figure 5) is consistent with measurements

272 from other years $(2009,2010,2015,2016)$, when only $\mathrm{NH}_{3}, \mathrm{NH}_{4}{ }^{+}, \mathrm{HNO}_{3}, \mathrm{NO}_{3}{ }^{-}$, and $\mathrm{NO}_{\mathrm{y}}$ were

273 measured. The four other study years measured $\mathrm{NO}_{\mathrm{y}}, \mathrm{NH}_{3}$ and $\mathrm{NH}_{4}{ }^{+}$from July through October. 
274 In this 2014 FRAPPÉ study the total RN was $1.6 \mathrm{ppb}$ compared to $1.9-2.6 \mathrm{ppb}$ in the other four 275 studies.

276 Alkyl nitrates were measured for the first time in ROMO during the 2014 FRAPPÉ study.

277 The alkyl nitrates measured here are primarily formed by oxidation of hydrocarbons emitted 278 from fossil fuels (ethane, butane, pentane) and generally contribute less than $10 \%$ to $\mathrm{NO}_{\mathrm{y}}$ in 279 continental regions (Russo et al., 2010a). Measurements of alkyl nitrates during FRAPPÉ were 280 consistent with this, contributing $4 \%$ to $\mathrm{NO}_{\mathrm{y}}$ and $2.7 \%$ to the total atmospheric $\mathrm{RN}$ budget 281 during FRAPPÉ (Figure 5). The measured alkyl nitrates were primarily composed of i-propyl 282 nitrate (26\%), methyl nitrate (25\%), and 2-butyl nitrate (23\%). The remaining 26\% were ethyl 283 nitrate $(9 \%)$, n-propyl nitrate $(6 \%)$, 2-pentyl nitrate $(5 \%)$, and 3-pentyl nitrate $(6 \%)$. All of the 284 alkyl nitrate concentrations were highly correlated with each other, except methyl nitrate (Figure 285 6). Whereas all of the other alkyl nitrates measured are primarily photochemical oxidation 286 products, methyl nitrate $\left(\mathrm{MeONO}_{2}\right)$ has both a photochemical and marine source. To examine 287 the influence of a potential marine influence, we examined the relationship between ethyl nitrate $288\left(\mathrm{EtONO}_{2}\right)$ and $\mathrm{MeONO}_{2}$ colored by $\mathrm{CHBr}_{3}$ (Figure $\left.6 \mathrm{~b}\right)$, a tracer for marine air (Gschwend, 289 MacFarlane \& Newman, 1985; Carpenter et al., 2005). As seen in the figure, $\mathrm{MeONO}_{2}$ is 290 enhanced during periods with elevated $\mathrm{CHBr}_{3}$, suggesting that, although $\mathrm{ROMO}$ is relatively 291 distant from marine sources, the park can be measurably influenced by marine air. Previous 292 results from HYSPLIT back trajectories for the same site showed that air masses from the Pacific 293 Ocean make it to ROMO (Gebhart et al., 2014), but this is the first chemical evidence of marine 294 air masses at ROMO. Other possible contributing factors for the low correlation between $295 \mathrm{MeONO}_{2}$ and the other alkyl nitrates may be the relatively higher solubility (faster scavenging by 296 precipitation) and longer lifetime (oxidation and photolysis) of $\mathrm{MeONO}_{2}$ (Russo et al., 2010a). 


\subsection{Nitrogen Deposition}

299 Atmospheric nitrogen can be deposited to the surface of the earth by wet and dry

300 deposition. Nitrogen in wet deposition comes from activation of cloud condensation nuclei

$301(\mathrm{CCN})$ and subsequent scavenging of gases and non-activated aerosols by cloud droplets, rain,

302 and snow. Dry deposition is direct deposition of particles and gases to the surface. Dry

303 deposition is more difficult to quantify than wet deposition because it is difficult to measure

304 directly, and modeled estimates can depend on chemistry and environmental factors including

305 relative humidity, temperature, atmospheric turbulence, boundary layer thickness, and the

306 surface to which deposition occurs (Tarnay et al., 2001).

307

308

Wet Deposition

309 Consistent with previous ROMO studies (Beem et al., 2010; Benedict et al., 2013a) wet

310 deposition dominated the total nitrogen deposition budget during FRAPPÉ, contributing $0.79 \mathrm{~kg}$

$311 \mathrm{~N} /$ ha or $85 \%$ to total nitrogen deposition (Figure 7). Ammonium contributed $49 \%, \mathrm{NO}_{3}{ }^{-}$

312 contributed $34 \%$, and organic nitrogen contributed only $2 \%$ to total nitrogen deposition for July

313 17-August 31. While the fraction of organic nitrogen measured in the gas phase was much higher

314 than $2 \%\left(\sum \mathrm{R}-\mathrm{ONO}_{2(\mathrm{~g})}+\mathrm{PAN}_{(\mathrm{g})}=22 \%\right)$ this fraction is likely to be lower in precipitation due to

315 the significantly lower solubility of the different organic nitrogen gases (relative to ammonia and

316 nitric acid), and due to potential for loss in collected samples.

317 The fraction of organic nitrogen $(\mathrm{ON})$ within individual events varied greatly in summer

3182014 , from $0 \%$ (ON below detection) to 20\%. Although the average wet deposition of ON was

319 less than we have previously observed at this location, the upper bound is consistent with 
320 measurements during the 2009 RoMANS study, when the average ON fraction in late summer

321 and early fall was at 20\% (Benedict et al., 2013a). Understanding the cause for the differences in

322 the two study years is difficult, because we quantify bulk organic nitrogen and not individual

323 species, which provides little information on source types.

324

At the measurement site in ROMO average precipitation from July to September for the

325

326

327

328

329

330

331

332

333

334

335

336

337

338

339

340

341

period of 1995-2016 is $179 \mathrm{~mm}$. Annually the changes can be quite large; the standard deviation is $98 \mathrm{~mm}$. Table 2 summarizes the precipitation and wet nitrogen deposition for 2009, 2010, and 2014-2016. In 2014 total precipitation from July to September was well above average (222 $\mathrm{mm}$ ) and a large fraction of it (63 $\mathrm{mm}$ or 32\%) fell during upslope wind events (surface winds $\left.70-180^{\circ}\right)$, resulting in high wet deposition values. This is a consistent trend we observed at the ROMO site, years with high precipitation, especially large upslope precipitation fractions tend to have the highest wet $\mathrm{N}$ deposition (for example 2009). For the years we have data, 2015 is a case with a lower fraction of precipitation occurring during upslope flow conditions and the lowest wet $\mathrm{N}$ deposition likely due to variations in synoptic and local circulation. The variability in precipitation patterns is an important driver in the total $\mathrm{N}$ deposition observed due to the importance of wet deposition at the site. Additionally, the fraction of reduced nitrogen or oxidized in the wet deposition do not show any trend with the amount or fraction of precipitation associated with upslope flow, or the fraction of time upslope occurred. Specifically, the largest reduced fraction (66\%) was measured in 2016 and the smallest (46\%) in 2009 and neither of these years stand out in the parameters we've examined in Table 2.

Dry Deposition 
342 For estimating dry deposition during FRAPPÉ, we used a multi-faceted approach,

343 depending on the data. For daily data, we used the monthly average diurnal cycle of deposition

344 velocity $\left(\mathrm{V}_{\mathrm{d}}\right)$ from CASTNET (U.S. Environmental Protection Agency Clean Air Markets

345 Division, 2016b) to determine $\mathrm{V}_{\mathrm{d}}$ for $\mathrm{HNO}_{3}, \mathrm{NO}_{3}^{-}$, and $\mathrm{NH}_{4}^{+}$, and then applied these hourly $\mathrm{V}_{\mathrm{d}}$

346 values to the 24 hour average concentrations observed (average $\mathrm{V}_{\mathrm{d}}\left(\mathrm{HNO}_{3}\right)=1.8 \mathrm{~cm} / \mathrm{s}$,

$\left.347 \mathrm{~V}_{\mathrm{d}}\left(\mathrm{PM}_{2.5}\right)=0.20 \mathrm{~cm} / \mathrm{s}\right)$. The diurnal cycle for $\mathrm{V}_{\mathrm{d}}$ was based on monthly average hourly values of

348 all available deposition velocities at the ROMO site (1/1995-1/2014). For $\mathrm{NH}_{3}$, which is

349 measured at higher time resolution (1-hr), hourly averages were taken from historical data

$350(1 / 1995-1 / 2014)$ for $\mathrm{V}_{\mathrm{d}}\left(\mathrm{HNO}_{3}\right)$ and were scaled by 0.7 based on a literature survey of co-located

$351 \mathrm{HNO}_{3}$ and $\mathrm{NH}_{3} \mathrm{~V}_{\mathrm{d}}$ measurements (Benedict et al., 2013b,a) (average $\mathrm{V}_{\mathrm{d}}\left(\mathrm{NH}_{3}\right)=1.25 \mathrm{~cm} / \mathrm{s}$ ).

352 This may overestimate actual net deposition of $\mathrm{NH}_{3}$ given the importance of bi-directional

353 exchange (Li et al., 2016; Wentworth et al., 2016). Finally, for other gas phase nitrogen species

354 that are not measured or modeled by CASTNET, we examined literature values of fluxes and

355 deposition velocities to estimate their contributions to the nitrogen deposition budget during

356 FRAPPÉ, as discussed below.

357 Estimating dry deposition of $\mathrm{NO}_{\mathrm{y}}$ is difficult due to the variability in $\mathrm{NO}_{\mathrm{y}}$ composition

358 across study sites and at different times of year. To that end we have estimated the dry

359 deposition of the separate components measured. Hourly deposition velocities for PAN were

360 taken from Turnipseed et al. (2006) for a Loblolly pine forest in North Carolina (daily average

$3610.52 \mathrm{~cm} / \mathrm{s}$ ). However, we note that Wolfe et al. (2009) published hourly values of PAN

362 deposition velocities for a Ponderosa pine forest in the Sierra Nevada mountains that are

363 significantly lower than Turnipseed values (average $=0.17 \mathrm{~cm} / \mathrm{s}$ ). We use the higher Turnipseed

364 values to provide an upper limit for deposition for PAN. This corresponds to a factor of $\sim 2.7$ 
365 difference in the total dry deposition of PAN based on these estimates of $\mathrm{V}_{\mathrm{d}}$. Dry deposition of

366 alkyl nitrates was estimated using the nighttime $V_{d}(0.13 \mathrm{~cm} / \mathrm{s})$ from Russo et al. (2010a), one of

367 the few published studies that estimates an alkyl nitrate deposition velocity. The contribution of

368 dry NO deposition to total $\mathrm{N}$ deposition has been neglected, as atmospheric chemical reaction is

369 the primary means of removal in the lower atmosphere due to the low solubility and oxidizing

370 capacity of NO (Wesely \& Hicks, 2000) and low NO concentrations. In order to provide some

371 estimate of fluxes of the unspeciated components of $\mathrm{NO}_{z}$, dry deposition was calculated using

372 the average hourly and monthly $(1 / 1995-1 / 2014) \mathrm{O}_{3}$ deposition velocities from CASTNET

373 (Clarke, Edgerton \& Martin, 1997; Schwede et al., 2011) scaled by 0.67 (Wesely \& Hicks, 2000)

$374 \quad$ average $\left.\mathrm{V}_{\mathrm{d}}\left(\mathrm{NO}_{\mathrm{z}}\right)=0.12 \mathrm{~cm} / \mathrm{s}\right)$.

375 Estimated dry deposition contributed $0.14 \mathrm{~kg} \mathrm{~N} / \mathrm{ha}$, or $15 \%$, of total deposition in ROMO

376 during the FRAPPÉ period. Dry deposition was dominated by $\mathrm{NH}_{3}(57 \% ; 0.08 \mathrm{kgN} / \mathrm{ha})$

377 followed by $\mathrm{HNO}_{3}(17 \% ; 0.024 \mathrm{kgN} / \mathrm{ha})$, PAN (13\%; $\left.0.018 \mathrm{kgN} / \mathrm{ha}\right)$, and $\mathrm{NO}_{z}(7 \% ; 0.01$

$378 \mathrm{kgN} / \mathrm{ha})$. Of the dry deposited species, $\mathrm{NH}_{3}$ contributes the most to total deposition (8.6\%).

379 Species that are newly measured in this study have small contributions to total nitrogen

380 deposition, including PAN (2\%), $\mathrm{NO}_{z}(1 \%)$, and alkyl nitrates $(0.1 \% ; 0.005 \mathrm{kgN} / \mathrm{ha})$, which are

381 of similar importance to $\mathrm{HNO}_{3}(2.5 \%), \mathrm{NH}_{4}{ }^{+}(0.8 \%)$ and $\mathrm{NO}_{3}^{-}(0.1 \%)$ dry deposition.

382 Wet nitrogen deposition is directly measured with $\sim 10 \%$ uncertainty and should be used

383 as a lower bound of total nitrogen deposition. Estimating the dry component of the nitrogen

384 deposition budget is fairly uncertain but does provide some idea of its potential importance.

385 Limitations of the method to determine dry deposition used here include using average $V_{d}$ from

386 the site instead of values for the meteorological conditions during the study, using non-site

387 specific values for $\mathrm{PAN}$ and $\mathrm{NO}_{\mathrm{y}}$, and not accounting for bi-directional exchange of $\mathrm{NH}_{3}$ but 
388 using the nitric acid $\mathrm{V}_{\mathrm{d}}$ ratio should account for some of this interaction. To truly get a handle on

389 the dry deposition component, and the uncertainty in the estimates made here, direct flux

390 measurements need to be made particularly since the dry components are not insignificant to the

391 total estimated nitrogen deposition budget.

392

393

$394 \quad 3.4$ Sources Impacting ROMO

The VOC measurements at ROMO during FRAPPÉ provide insight into the array of

potential sources and source regions that may contribute to excess nitrogen deposition in the

park. In an analysis of the VOC data from FRAPPÉ, Benedict et al. (2018) observed the

contribution of several sources impacting $\mathrm{O}_{3}$ at $\mathrm{ROMO}$, with some days showing more oil and

gas influence, while others had an increased urban influence.

400

Here we focus on compounds that help separate urban pollutants from those most likely

401

associated with oil and gas production. Tetrachloroethene $\left(\mathrm{C}_{2} \mathrm{Cl}_{4}\right)$ has been used extensively as a

402

tracer for urban air (Simpson et al., 2004) because it is used as a dry cleaning solvent and

403

degreasing agent. Ethane is mainly emitted to the atmosphere during the production, processing

404

and transportation of natural gas (Tzompa-Sosa et al., 2017). Table 3 displays the correlation

( $\mathrm{R}^{2}$-values) between the measured $\mathrm{RN}$ species and these two VOC tracers. A significant fraction

of the observed variability in $\mathrm{NO}_{\mathrm{y}}, \mathrm{PAN}$, and the alkyl nitrates (except $\mathrm{MeONO}_{2}$ ) can be

explained by the variability in these tracers. $\mathrm{NO}_{\mathrm{y}}$ is more strongly correlated with the urban

tracer, $\mathrm{C}_{2} \mathrm{Cl}_{4}$, while the alkyl nitrates are more strongly correlated with the oil and gas tracer,

ethane. PAN is not strongly correlated with either tracer likely because both sources types (oil

410 and gas/urban), long range transport, and photochemical processes contribute to observed 
411 concentrations. The strong correlation between alkyl nitrates and ethane is expected, since the

412 parent compounds of the alkyl nitrates (e.g. propane, butane, and pentane) come from similar

413 sources as ethane (Roberts, 1990). No significant increase in the correlation with any of the RN

414 compounds is observed when moving from a single regression to a multi-linear regression using

415 ethane and $\mathrm{C}_{2} \mathrm{Cl}_{4}$ (not shown).

416 The ratio of i-butane to n-butane has been used extensively to indicate the relative

417 importance of different VOC source types to an air parcel; low values of this ratio can

418 correspond to "wet" oil and gas production or transport (0.37 Marcellus Shale) (Swarthout et al.,

419 2015) and higher values of this ratio indicate rural air masses (0.52 New Hampshire) (Russo et

420 al., 2010b) or “dry” oil and gas production (1.07 Piceance, 0.685 Uintah) (Helmig et al., 2014;

421 Hilliard, 2016). In Figure 8 the tracer and nitrogen-containing compounds are plotted against the

422 i- to n-butane ratio to show how they align with the air masses measured in Denver during

423 FRAPPÉ (0.45) and a regional Denver-Julesburg (DJ) Basin value measured at the BAO tower

424 (0.40) (Swarthout et al., 2013). Individual points are colored by wind direction to provide some

425 information on the transport of the associated air masses and it is important to note, there is a

426 strong relationship between the i- to n-butane ratio with wind direction. For ethane, the highest

427 mixing ratios were observed when the $\mathrm{i}$ - to $\mathrm{n}$-butane ratios were near 0.4 , consistent with those

428 observed in the DJ Basin. There was significantly more scatter observed for mixing ratios $<2$

429 ppb, suggesting mixing of air masses that have been transported over a longer distance. Elevated

430 mixing ratios of PAN and $\mathrm{NO}_{\mathrm{y}}$ were associated with $\mathrm{i}$ - to $\mathrm{n}$-butane ratios near both Denver and

431 the DJ Basin, while elevated mixing ratios of the alkylnitrates, which are primarily oxidation

432 products of the light alkanes, were observed when i- to n-butane ratios matched those observed

433 within the nearby DJ basin. For $\mathrm{NH}_{3}$, there was a lot of scatter in i- to n-butane ratios at mixing 
434 ratios below $1.5 \mathrm{ppb}$; however, higher mixing ratios were associated with $\mathrm{i}$ - to $\mathrm{n}$-butane ratios

435 similar to those observed within the nearby DJ basin. This likely results due to oil and gas

436 operations being collocated with extensive agricultural operations in this basin.

437 If we extend the analysis from Figure 6 where we observed the influence of long range

438 transport using high concentrations of $\mathrm{CHBr}_{3}$ and ratios of $\mathrm{MeONO}_{2} / \mathrm{EtONO}_{2}>3$ to the reactive

439 nitrogen species we observe that in some cases the reactive nitrogen species are elevated but not

440 significantly (Figure 9). The concentrations of alkylnitrates and $\mathrm{NO}_{\mathrm{y}}$ during periods when long

441 range transport was most likely to occur, $\mathrm{CHBr}_{3}>1 \mathrm{ppbv}$ and higher ratios of $\mathrm{MeONO}_{2} / \mathrm{EtONO}_{2}$,

442 are low and near zero. PAN shows slight elevation during these conditions which is expected

443 due to the greater potential for long range transport at high altitudes and cooler temperatures.

444 However, the majority of high PAN concentrations were not observed under these conditions.

445 Ammonia shows a different pattern with more spread in the concentrations observed at higher

$446 \mathrm{CHBr}_{3}$, some of this variability may be due to local $\mathrm{CHBr}_{3}$ emissions associated with a waste

447 water treatment plant but there are few data available that examine $\mathrm{CHBr}_{3}$ emissions from this

448 type of source (Gschwend, MacFarlane \& Newman, 1985; Carpenter et al., 2005). Using this

449 metric is imperfect due to the potential for other sources to contribute to elevated $\mathrm{CHBr}_{3}$, but still

450 the observations with the high ratio of $\mathrm{MeONO}_{2} / \mathrm{EtONO}_{2}$ are more likely to be from long range

451 transport while the other points are more likely to be associated with transport from the Front 452 Range.

453

454

455

456

457

\subsection{Conclusions}

Measurements made at ROMO during the FRAPPÉ study in 2014 provided an opportunity to add measurements of $\mathrm{RN}$ that had not been previously made at the site (PAN, alkyl nitrates) and to try to connect observed species and their abundances with specific tracer 
458 species to better understand the source regions. In the atmospheric $\mathrm{RN}$ budget the relative

459 importance of urban/combustion and rural/agricultural influence is often viewed as the

460 oxidized/reduced nitrogen ratio; however, the rural eastern plains of Colorado are strongly

461 influenced by both agriculture and oil and gas operations, the latter offering significant $\mathrm{NO}_{\mathrm{x}}$

462 emissions (Duncan et al., 2016). So while RN is dominated by oxidized nitrogen in the gas

463 phase, it is not clear that urban air is the dominant contributor of RN deposition to ROMO. In

464 deposition, reduced nitrogen is the major component. The differing importance of reduced

465 (more in precipitation) and oxidized (more in the atmosphere) nitrogen species in the gas and the

466 aqueous phase is a reflection of the different solubilities and abilities to be scavenged based on

467 the properties of the individual species. It also suggests that emissions from many types of

468 sources are important for the observed air mass composition and deposition at ROMO.

469 In this study we observed evidence that emissions from oil and gas operations, urban

470 sources, and long range transport impact ROMO and affect atmospheric reactive nitrogen. The

471 use of VOC tracers confirmed previous measurement (Benedict et al., 2013c) and modeling

472 (Gebhart et al., 2011; Thompson et al., 2015) studies that identified these sources as important in

473 the region. The spatial overlap of agricultural and oil and gas operation sources in eastern

474 Colorado indicate agriculture is also an important source of reactive nitrogen even though we did

475 not use a specific tracer for the source. Other measurements of ammonia and the other RN

476 species, beyond this study, were made during FRAPPÉ. Specifically, there are mobile and

477 aircraft measurements that should be analyzed to determine if more information about specific

478 sources in NE Colorado can be identified. Further analysis of the extensive FRAPPÉ dataset is

479 beyond the scope of the current study. However, it would be beneficial to do a more 
480 comprehensive analysis of the FRAPPÉ aircraft data using the ROMO site as a point of reference

481 to better understand the spatial variability of these species.

482 Previous nitrogen deposition budgets constructed for $\mathrm{ROMO}$ lacked $\mathrm{NO}_{\mathrm{y}}$ and gas phase

483 organic nitrogen compounds as part of the dry deposition budget (Beem et al., 2010; Benedict et

484 al., 2013a). As seen in previous work, the nitrogen deposition budget at ROMO is dominated by

485 wet deposition, specifically $\mathrm{NH}_{4}{ }^{+}$followed by $\mathrm{NO}_{3}{ }^{-}$. Our estimates of dry deposition suggest that

486 reduced nitrogen (specifically $\mathrm{NH}_{3}$ ) is the largest contributor to the dry deposition budget. This is

487 the first study in ROMO that includes deposition estimates of PAN (1.9\% of total N deposition)

488 and alkyl nitrates $(0.06 \%$ of total $\mathrm{N}$ deposition $)$. Although their contributions were relatively

489 small, it is important to examine all components of the nitrogen deposition budget to better

490 understand the role of various sources to nitrogen deposition and better constrain the deposition

491 budget. Providing tighter constraints would require measurements of dry deposition, rather than

492 the inferential estimates as done here. We also lack information on bi-directional fluxes, of $\mathrm{NH}_{3}$

493 in particular, needed to better understand the deposition budget at ROMO.

495 Acknowledgements

496 The assumptions, findings, conclusions, judgments, and views presented herein are those of the

497 authors and should not be interpreted as necessarily representing the National Park Service.

498 Meteorological data were provided by the National Park Service. We would like to recognize

499 the contributions of the FRAPPÉ/Discover-AQ PIs (Gabriele Pfister-NCAR, Frank Flocke-

500 NCAR, Jim Crawford, NASA) for their contributions in organizing and directing the experiment

501 including the flight and measurement planning and field operations. 
503

504

505

506

507

508

509

510

511

512

513

514

515

516

517

518

519

520

521

522

523

524

525

526

References

Abeleira A., Pollack IB., Sive B., Zhou Y., Fischer EV., Farmer DK. 2017. Source

characterization of volatile organic compounds in the Colorado Northern Front Range Metropolitan Area during spring and summer 2015. Journal of Geophysical Research: Atmospheres 122:2016JD026227. DOI: 10.1002/2016JD026227.

Amec Foster Wheeler. 2016. Appendix 11: Quality Assurance Plan for Procuring, Installing, and Operating NCore Air Monitoring Equipment at CASTNET sites.

Baron JS. 2006. Hindcasting nitrogen deposition to determine an ecological critical load. Ecological Applications 16:433-439. DOI: 10.1890/1051-0761.

Baron JS., Del Grosso S., Ojima DS., Theobald DM., Parton WJ. 2004. Nitrogen emissions along the Colorado Front Range: Response to population growth, land and water use change, and agriculture. In: DeFries RS, Asner GP, Houghton RA eds. Geophysical Monograph Series. Washington, D. C.: American Geophysical Union, 117-127.

Baron J., Ojima D., Holland E., Parton W. 1994. Analysis of Nitrogen Saturation Potential in Rocky-Mountain Tundra and Forest - Implications for Aquatic Systems. Biogeochemistry $27: 61-82$.

Beem KB., Raja S., Schwandner FM., Taylor C., Lee T., Sullivan AP., Carrico CM., McMeeking GR., Day D., Levin E., Hand J., Kreidenweis SM., Schichtel B., Malm WC., Collett JL. 2010. Deposition of reactive nitrogen during the Rocky Mountain Airborne Nitrogen and Sulfur (RoMANS) study. Environmental Pollution 158:862-872. DOI:

10.1016/j.envpol.2009.09.023.

Bell MD., Phelan J., Blett TF., Landers D., Nahlik AM., Van Houtven G., Davis C., Clark CM., Hewitt J. 2017. A framework to quantify the strength of ecological links between an 
environmental stressor and final ecosystem services. Ecosphere 8:n/a-n/a. DOI: $10.1002 /$ ecs 2.1806.

529 Benedict KB., Carrico CM., Kreidenweis SM., Schichtel B., Malm WC., Collett JL. 2013a. A seasonal nitrogen deposition budget for Rocky Mountain National Park. Ecological Applications 23:1156-1169. DOI: 10.1890/12-1624.1.

532

533

Benedict KB., Chen X., Sullivan AP., Li Y., Day D., Prenni AJ., Levin EJT., Kreidenweis SM., Malm WC., Schichtel BA., others 2013b. Atmospheric concentrations and deposition of reactive nitrogen in Grand Teton National Park. Journal of Geophysical Research: Atmospheres 118:11,875-11,887. DOI: 10.1002/2013JD020394.

Benedict KB., Day D., Schwandner FM., Kreidenweis SM., Schichtel B., Malm WC., Collett JL. 2013c. Observations of atmospheric reactive nitrogen species in Rocky Mountain National Park and across northern Colorado. Atmospheric Environment 64:66-76. DOI: 10.1016/j.atmosenv.2012.08.066.

Benedict KB., Prenni AJ., Carrico CM., Sullivan AP., Schichtel BA., Collett Jr. JL. 2017. Enhanced concentrations of reactive nitrogen species in wildfire smoke. Atmospheric Environment 148:8-15. DOI: 10.1016/j.atmosenv.2016.10.030.

Benedict KB., Zhou Y., Sive BC., Prenni AJ., Gebhart KA., Fischer EV., Evanoski-Cole A., Sullivan AP., Callahan S., Schichtel BA., Mao H., Zhou Y., Collett Jr. JL. 2018. Volatile Organic Compounds and Ozone in Rocky Mountain National Park during FRAPPÉ. Atmos. Chem. Phys. Discuss. 2018:1-42. DOI: 10.5194/acp-2018-375.

Bowman WD., Steltzer H. 1998. Positive feedbacks to anthropogenic nitrogen deposition in Rocky Mountain Alpine tundra. Ambio 27:514-517. 
549 Brown. S., Dibb, J. E., Stark, H., Aldener, M., Vozella M., Whitlow, S., Williams, E. J., Lerner,

550

551

552

553

554

555

556

557

558

559

560

561

562

563

564

565

566

567

568

569

B. M., Jakoubek, R., Middlebrook, A. M., DeGouw, J. A., Warneke, C., Goldan, P. D., Kuster, W. C., Angevine, W. M., Sueper, D. T., Quinn, P. K., Bates, T. S., Meagher, J. F., Fehsenfeld, F. C., Ravishankara, A. R. 2004. Nighttime removal of NOx in the summer marine boundary layer. Geophysical Research Letters 31. DOI: 10.1029/2004GL019412.

Brown SS., Ryerson TB., Wollny AG., Brock CA., Peltier R., Sullivan AP., Weber RJ., Dubé WP., Trainer M., Meagher JF., Fehsenfeld FC., Ravishankara AR. 2006. Variability in Nocturnal Nitrogen Oxide Processing and Its Role in Regional Air Quality. Science 311:67-70. DOI: 10.1126/science.1120120.

Brown SS., Stutz J. 2012. Nighttime radical observations and chemistry. Chemical Society Reviews 41:6405-6447. DOI: 10.1039/C2CS35181A.

Burns DA. 2003. Atmospheric nitrogen deposition in the Rocky Mountains of Colorado and southern Wyoming - a review and new analysis of past study results. Atmospheric Environment 37:921-932. DOI: 10.1016/S1352-2310(02)00993-7.

Burns DA. 2004. The effects of atmospheric nitrogen deposition in the Rocky Mountains of Colorado and southern Wyoming, USA - a critical review. Environmental Pollution 127:257-269. DOI: 10.1016/S0269-7491(03)00264-1.

Carpenter LJ., Wevill DJ., O’Doherty S., Spain G., Simmonds PG. 2005. Atmospheric bromoform at Mace Head, Ireland: seasonality and evidence for a peatland source. Atmos. Chem. Phys. 5:2927-2934. DOI: 10.5194/acp-5-2927-2005. 
570 CDPHE. 2017.Rocky Mountain National Park Initiative | Department of Public Health and

571 Environment. Available at https://www.colorado.gov/pacific/cdphe/rocky-mountain-

572 national-park-initiative (accessed February 21, 2017).

573 Clarke JF., Edgerton ES., Martin BE. 1997. Dry deposition calculations for the clean air status

$574 \quad$ and trends network. Atmospheric Environment 31:3667-3678. DOI: 10.1016/S1352-

$575 \quad 2310(97) 00141-6$.

576 Crosley DR. 1996. NO y Blue Ribbon panel. Journal of Geophysical Research: Atmospheres 101:2049-2052. DOI: 10.1029/95JD02276.

578 Day DA., Dillon MB., Wooldridge PJ., Thornton JA., Rosen RS., Wood EC., Cohen RC. 2003. On alkyl nitrates, O3, and the "missing NOy." Journal of Geophysical Research: Atmospheres 108:4501. DOI: 10.1029/2003JD003685.

581 Dingle JH., Vu K., Bahreini R., Apel EC., Campos TL., Flocke F., Fried A., Herndon S., Hills AJ., Hornbrook RS., Huey G., Kaser L., Montzka DD., Nowak JB., Reeves M., Richter D., Roscioli JR., Shertz S., Stell M., Tanner D., Tyndall G., Walega J., Weibring P., Weinheimer A. 2016. Aerosol optical extinction during the Front Range Air Pollution and Photochemistry Éxperiment (FRAPPÉ) 2014 summertime field campaign, Colorado, USA. Atmospheric Chemistry and Physics 16:11207-11217. DOI: 10.5194/acp-1611207-2016.

Duncan BN., Lamsal LN., Thompson AM., Yoshida Y., Lu Z., Streets DG., Hurwitz MM., Pickering KE. 2016. A space-based, high-resolution view of notable changes in urban NOx pollution around the world (2005-2014). Journal of Geophysical Research: Atmospheres 121:2015JD024121. DOI: 10.1002/2015JD024121. 
592 Fenn ME., Baron JS., Allen EB., Rueth HM., Nydick KR., Geiser L., Bowman WD., Sickman

593 JO., Meixner T., Johnson DW., Neitlich P. 2003. Ecological effects of nitrogen

594 deposition in the western United States. Bioscience 53:404-420. DOI: 10.1641/0006-

$595 \quad 3568(2003) 053[0404: E E O N D I] 2.0 . C O ; 2$.

596 Fenn ME., Poth MA., Aber JD., Baron JS., Bormann BT., Johnson DW., Lemly AD., McNulty SG., Ryan DE., Stottlemyer R. 1998. Nitrogen excess in North American ecosystems: Predisposing factors, ecosystem responses, and management strategies. Ecological Applications 8:706-733. DOI: 10.2307/2641261.

600 Flechard CR., Nemitz E., Smith RI., Fowler D., Vermeulen AT., Bleeker A., Erisman JW.,

601

602

603

604

605

606

607

608

609

610

611

612

613

614

Simpson D., Zhang L., Tang YS., Sutton MA. 2011. Dry deposition of reactive nitrogen to European ecosystems: a comparison of inferential models across the NitroEurope network. Atmospheric Chemistry and Physics 11:2703-2728. DOI: 10.5194/acp-11-27032011.

Galloway JN., Townsend AR., Erisman JW., Bekunda M., Cai Z., Freney JR., Martinelli LA., Seitzinger SP., Sutton MA. 2008. Transformation of the Nitrogen Cycle: Recent Trends, Questions, and Potential Solutions. Science 320:889-892. DOI:

10.1126/science. 1136674 .

Gebhart KA., Malm WC., Rodriguez MA., Barna MG., Schichtel BA., Benedict KB., Collett JL., Carrico CM. 2014. Meteorological and Back Trajectory Modeling for the Rocky Mountain Atmospheric Nitrogen and Sulfur Study II. Advances in Meteorology 2014:119. DOI: $10.1155 / 2014 / 414015$.

Gebhart KA., Schichtel BA., Malm WC., Barna MG., Rodriguez MA., Collett JL. 2011. Backtrajectory-based source apportionment of airborne sulfur and nitrogen concentrations at 

DOI: $10.1016 /$ j.atmosenv.2010.10.035.

617 Goulding KWT., Bailey NJ., Bradbury NJ., Hargreaves P., Howe M., Murphy DV., Poulton PR., 618 Willison TW. 1998. Nitrogen deposition and its contribution to nitrogen cycling and 619 associated soil processes. New Phytologist 139:49-58. DOI: 10.1046/j.14698137.1998.00182.x.

621 Gschwend PM., MacFarlane JK., Newman KA. 1985. Volatile Halogenated Organic Compounds 622 Released to Seawater from Temperate Marine Macroalgae. Science 227:1033-1035.

623 Helmig D., Thompson CR., Evans J., Boylan P., Hueber J., Park J-H. 2014. Highly Elevated 624 Atmospheric Levels of Volatile Organic Compounds in the Uintah Basin, Utah. Environmental Science \& Technology 48:4707-4715. DOI: 10.1021/es405046r.

Hilliard NG. 2016. Volatile organic compound and methane emissions from well development operations in the Piceance Basin. Thesis Thesis. Colorado State University. Libraries.

Howarth RW. 2004. Human acceleration of the nitrogen cycle: drivers, consequences, and steps toward solutions. Water Science and Technology 49:7-13.

Kondo Y., Kawakami S., Koike M., Fahey DW., Nakajima H., Zhao Y., Toriyama N., Kanada M., Sachse GW., Gregory GL. 1997. Performance of an aircraft instrument for the measurement of NOy. Journal of Geophysical Research: Atmospheres 102:28663-28671. DOI: $10.1029 / 96 J D 03819$.

634 LeBauer DS., Treseder KK. 2008. Nitrogen Limitation of Net Primary Productivity in Terrestrial 635 Ecosystems Is Globally Distributed. Ecology 89:371-379. DOI: 10.1890/06-2057.1. 
636 Lehmann CMB., Bowersox VC., Larson SM. 2005. Spatial and temporal trends of precipitation chemistry in the United States, 1985-2002. Environmental Pollution 135:347-361. DOI:

638 10.1016/j.envpol.2004.11.016.

Li Y. 2016. Characterizing ammonia concentrations and deposition in the United States. Thesis Thesis. Colorado State University. Libraries.

Liu X., Duan L., Mo J., Du E., Shen J., Lu X., Zhang Y., Zhou X., He C., Zhang F. 2011. Nitrogen deposition and its ecological impact in China: An overview. Environmental Pollution 159:2251-2264. DOI: 10.1016/j.envpol.2010.08.002.

Malm WC., Collett Jr JL., Barna MG., Beem KB., Carrico CM., Gebhart KA., Hand JL., Levin EJT., Rodriguez MA., Schichtel BA., Schwandner FM. 2009. RoMANS:Rocky Mountain Atmospheric Nitrogen and Sulfur Study Volume 1.

647 Owen SM., Leaver DS., Bealey WJ., Wilson R., Reis S., Sutton M. 2011. A new database for time-series monitoring data: the NitroEurope approach. iForest-Biogeosciences and Forestry 4:226. DOI: 10.3832/ifor0595-004.

651

Parrish DD., Buhr MP., Trainer M., Norton RB., Shimshock JP., Fehsenfeld FC., Anlauf KG., Bottenheim JW., Tang YZ., Wiebe HA., Roberts JM., Tanner RL., Newman L., Bowersox VC., Olszyna KJ., Bailey EM., Rodgers MO., Wang T., Berresheim H., Roychowdhury UK., Demerjiani KL. 1993. The total reactive oxidized nitrogen levels and the partitioning between the individual species at six rural sites in eastern North America. Journal of Geophysical Research: Atmospheres 98:2927-2939. DOI: 10.1029/92JD02384.

Prenni AJ., Levin EJT., Benedict KB., Sullivan AP., Schurman MI., Gebhart KA., Day DE., Carrico CM., Malm WC., Schichtel BA., Collett JL., Kreidenweis SM. 2014. Gas-phase 
659

660

661

662

663

664

665

666

667

668

669

670

671

672

673

674

675

676

677

678

679

680

reactive nitrogen near Grand Teton National Park: Impacts of transport, anthropogenic emissions, and biomass burning. Atmospheric Environment 89:749-756. DOI: 10.1016/j.atmosenv.2014.03.017.

Roberts J. 1990. The Atmospheric Chemistry of Organic Nitrates. Atmospheric Environment Part a-General Topics 24:243-287. DOI: 10.1016/0960-1686(90)90108-Y.

Russo RS., Zhou Y., Haase KB., Wingenter OW., Frinak EK., Mao H., Talbot RW., Sive BC. 2010a. Temporal variability, sources, and sinks of C1-C5 alkyl nitrates in coastal New England. Atmos. Chem. Phys. 10:1865-1883. DOI: 10.5194/acp-10-1865-2010.

Russo RS., Zhou Y., White ML., Mao H., Talbot R., Sive BC. 2010b. Multi-year (2004-2008) record of nonmethane hydrocarbons and halocarbons in New England: seasonal variations and regional sources. Atmos. Chem. Phys. 10:4909-4929. DOI: 10.5194/acp10-4909-2010.

Schwede D., Zhang L., Vet R., Lear G. 2011. An intercomparison of the deposition models used in the CASTNET and CAPMoN networks. Atmospheric Environment 45:1337-1346. DOI: 10.1016/j.atmosenv.2010.11.050.

Simpson IJ., Meinardi S., Blake NJ., Rowland FS., Blake DR. 2004. Long-term decrease in the global atmospheric burden of tetrachloroethene (C2C14). Geophysical Research Letters 31:L08108. DOI: 10.1029/2003GL019351.

Sive BC., Zhou Y., Troop D., Wang Y., Little WC., Wingenter OW., Russo RS., Varner RK., Talbot R. 2005. Development of a Cryogen-Free Concentration System for Measurements of Volatile Organic Compounds. Analytical Chemistry 77:6989-6998. DOI: $10.1021 / \mathrm{ac} 0506231$. 
681 Swarthout RF., Russo RS., Zhou Y., Hart AH., Sive BC. 2013. Volatile organic compound

682

683

684

685

686

687

688

689

690

691

692

693

694

695

696

697

698

699

700

701

702

703

distributions during the NACHTT campaign at the Boulder Atmospheric Observatory: Influence of urban and natural gas sources. Journal of Geophysical Research: Atmospheres 118:10,614-10,637. DOI: 10.1002/jgrd.50722.

Swarthout RF., Russo RS., Zhou Y., Miller BM., Mitchell B., Horsman E., Lipsky E., McCabe DC., Baum E., Sive BC. 2015. Impact of Marcellus Shale Natural Gas Development in Southwest Pennsylvania on Volatile Organic Compound Emissions and Regional Air Quality. Environmental Science \& Technology 49:3175-3184. DOI: 10.1021/es504315f.

Tarnay L., Gertler AW., Blank RR., Taylor GE. 2001. Preliminary measurements of summer nitric acid and ammonia concentrations in the Lake Tahoe Basin air-shed: implications for dry deposition of atmospheric nitrogen. Environmental Pollution 113:145-153. DOI: $10.1016 / \mathrm{S} 0269-7491(00) 00168-8$.

Thompson TM., Rodriguez MA., Barna MG., Gebhart KA., Hand JL., Day DE., Malm WC., Benedict KB., Collett JL., Schichtel BA. 2015. Rocky Mountain National Park reduced nitrogen source apportionment. Journal of Geophysical Research: Atmospheres 120:2014JD022675. DOI: 10.1002/2014JD022675.

Thornberry T., Carroll MA., Keeler GJ., Sillman S., Bertman SB., Pippin MR., Ostling K., Grossenbacher JW., Shepson PB., Cooper OR., Moody JL., Stockwell WR. 2001. Observations of reactive oxidized nitrogen and speciation of NO y during the PROPHET summer 1998 intensive. Journal of Geophysical Research: Atmospheres 106:24359_ 24386. DOI: 10.1029/2000JD900760.

Turnipseed AA., Huey LG., Nemitz E., Stickel R., Higgs J., Tanner DJ., Slusher DL., Sparks JP., Flocke F., Guenther A. 2006. Eddy covariance fluxes of peroxyacetyl nitrates (PANs) 
and NOy to a coniferous forest. Journal of Geophysical Research: Atmospheres

705 111:D09304. DOI: 10.1029/2005JD006631.

706 Tzompa-Sosa ZA., Mahieu E., Franco B., Keller CA., Turner AJ., Helmig D., Fried A., Richter

707 D., Weibring P., Walega J., Yacovitch TI., Herndon SC., Blake DR., Hase F., Hannigan

708 JW., Conway S., Strong K., Schneider M., Fischer EV. 2017. Revisiting global fossil fuel

709 and biofuel emissions of ethane. Journal of Geophysical Research: Atmospheres

710 122:2016JD025767. DOI: 10.1002/2016JD025767.

711 U.S. Environmental Protection Agency Clean Air Markets Division. 2016a.Clean Air Status and Trends Network (CASTNET). Available at www.epa.gov/castnet (accessed April 27, 2016).

714 U.S. Environmental Protection Agency Clean Air Markets Division. 2016b.Clean Air Status and Trends Network (CASTNET). Available at www.epa.gov/castnet (accessed July 21, 2016).

717

US EPA. 2017. CASTNET Annual Report 2014.

718 Wentworth GR., Murphy JG., Benedict KB., Bangs EJ., Collett Jr. JL. 2016. The role of dew as a night-time reservoir and morning source for atmospheric ammonia. Atmos. Chem. Phys. Atmospheric Environment 34:2261-2282. DOI: 10.1016/S1352-2310(99)00467-7. SR., Nunnermacker LJ., Newman L., Olszyna K., Meagher J., Hartsell B., Edgerton E., Pearson JR., Rodgers MO. 1998. Intercomparison of ground-based NO y measurement 
techniques. Journal of Geophysical Research: Atmospheres 103:22261-22280. DOI:

727 10.1029/98JD00074.

728 Wolfe GM., Thornton JA., Yatavelli RLN., McKay M., Goldstein AH., LaFranchi B., Min K-E., 729 Cohen RC. 2009. Eddy covariance fluxes of acyl peroxy nitrates (PAN, PPN and MPAN) 730 above a Ponderosa pine forest. Atmos. Chem. Phys. 9:615-634. DOI: 10.5194/acp-9-615$731 \quad 2009$.

732 Zaragoza J., Callahan S., McDuffie EE., Kirkland J., Brophy P., Durrett L., Farmer DK., Zhou

733 Y., Sive B., Flocke F., Pfister G., Knote C., Tevlin A., Murphy J., Fischer EV. 2017.

734 Observations of acyl peroxy nitrates during the Front Range Air Pollution and

735 Photochemistry Éxperiment (FRAPPÉ). Journal of Geophysical Research:

736 Atmospheres:2017JD027337. DOI: 10.1002/2017JD027337.

737

738

739 


\section{Figure 1}

Map of the study region.

Included are the sampling site (star), cities along the northern Front Range of Colorado, oil and gas wells (pink) (COGCC, 2018), and confined animal feeding operations (purple), scaled by permitted number of animals allowed (CDPHE).

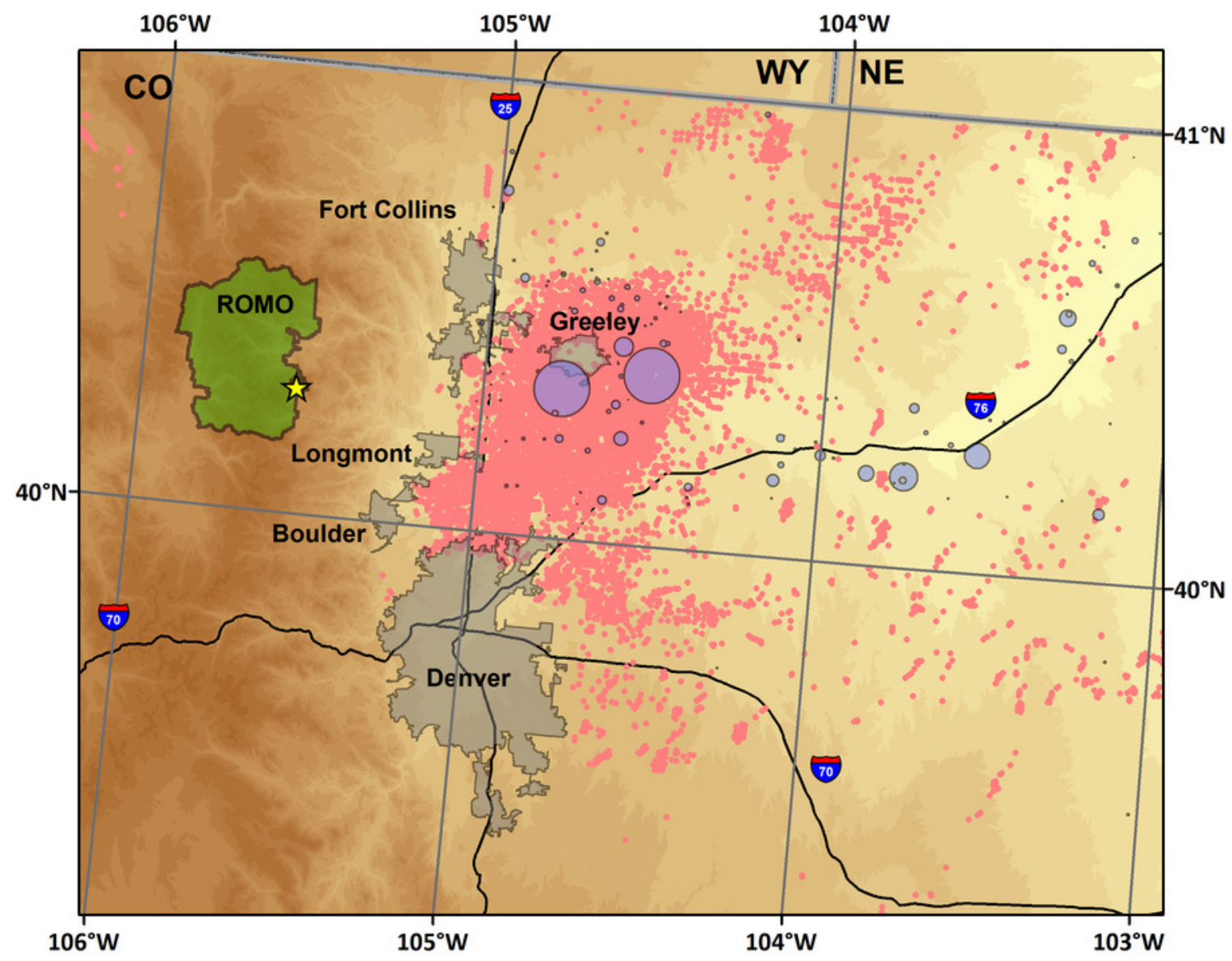


Figure 2

Timelines of reactive nitrogen and tracer species from July 16 to Sept 1, 2014 with wind direction and precipitation.

In (a), the shaded region represents upslope flow at the sampling site.
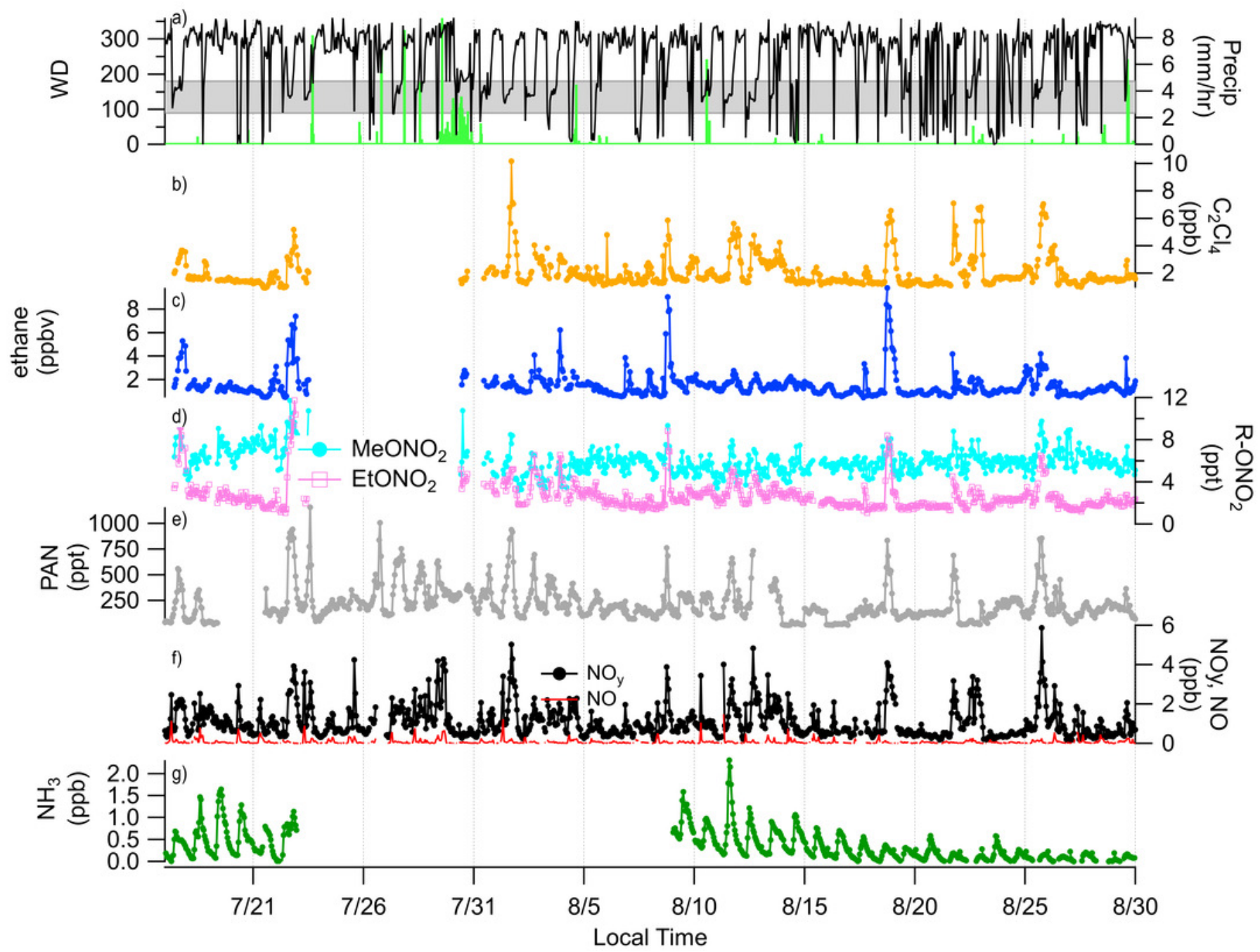
Figure 3

Frequency of PAN concentrations by wind direction.

Distance from the center represents the fraction of time winds were from a given $20^{\circ}$ wind sector and the colors in each paddle indicate the relative amounts of time concentrations of PAN were in a given concentration range.

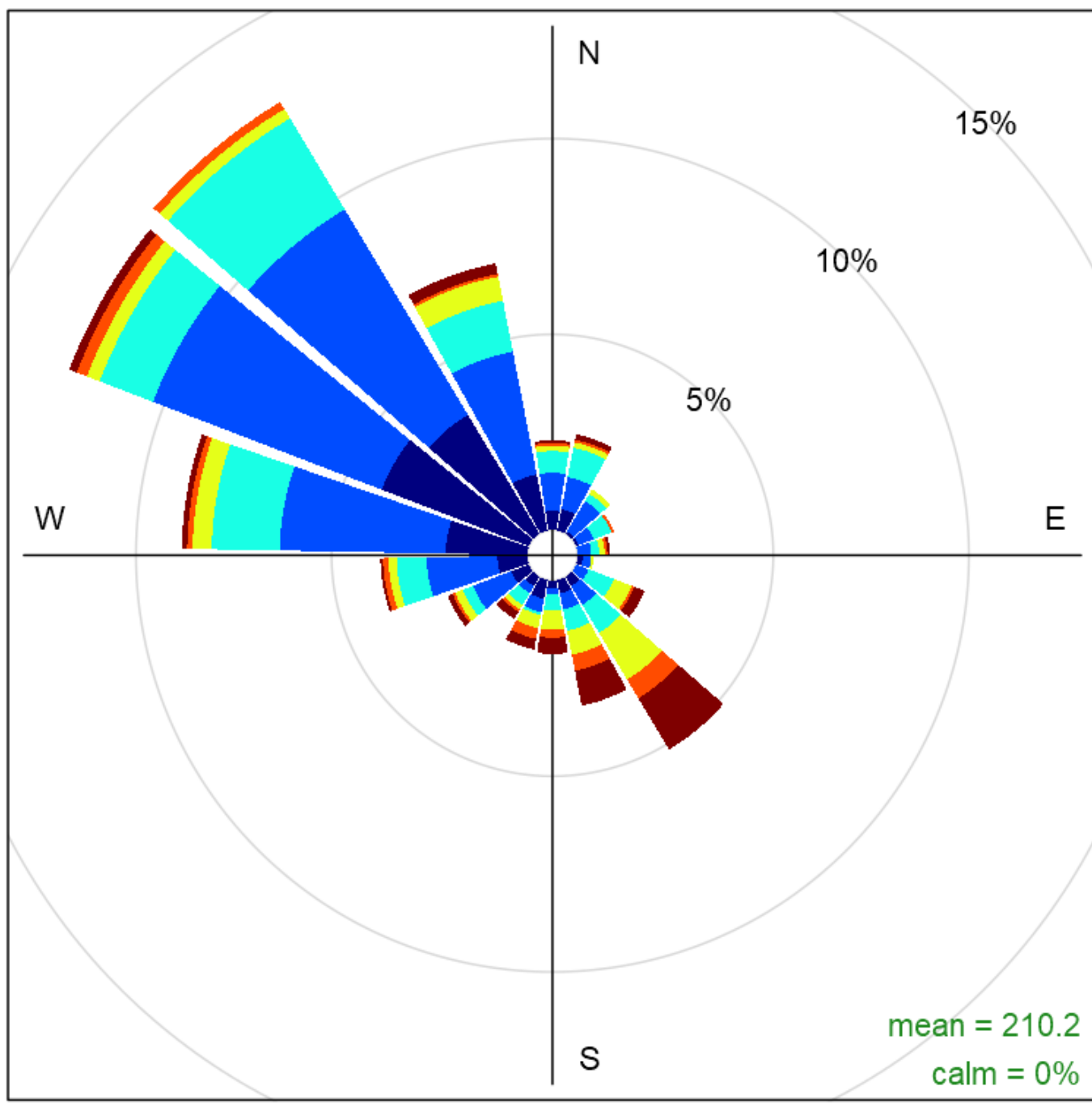

PAN (ppt)

500 to 1157.8

400 to 500

300 to 400

200 to 300

100 to 200

0 to 100

PAN

Frequency of counts by wind direction (\%) 
Figure 4

Diurnal averages and standard deviation of key RN and tracer species measured at ROMO from August 9 to August 31 with each valid measurement from every hour shown at the dots. 


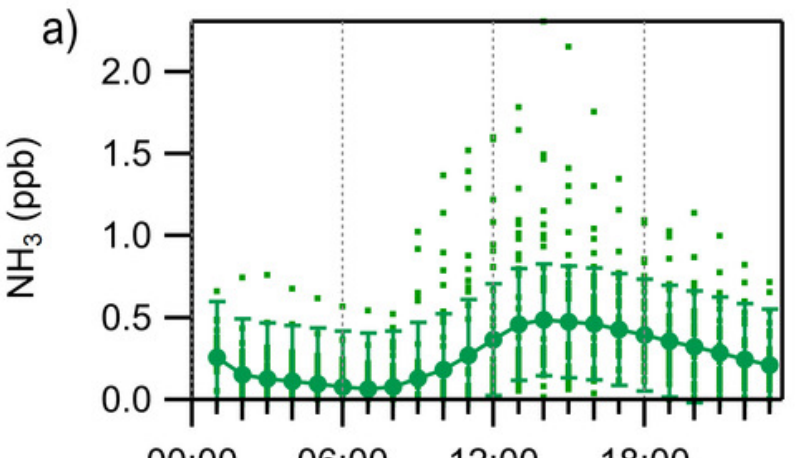

c) $\quad 00: 00 \quad 06: 00 \quad 12: 00 \quad 18: 00$
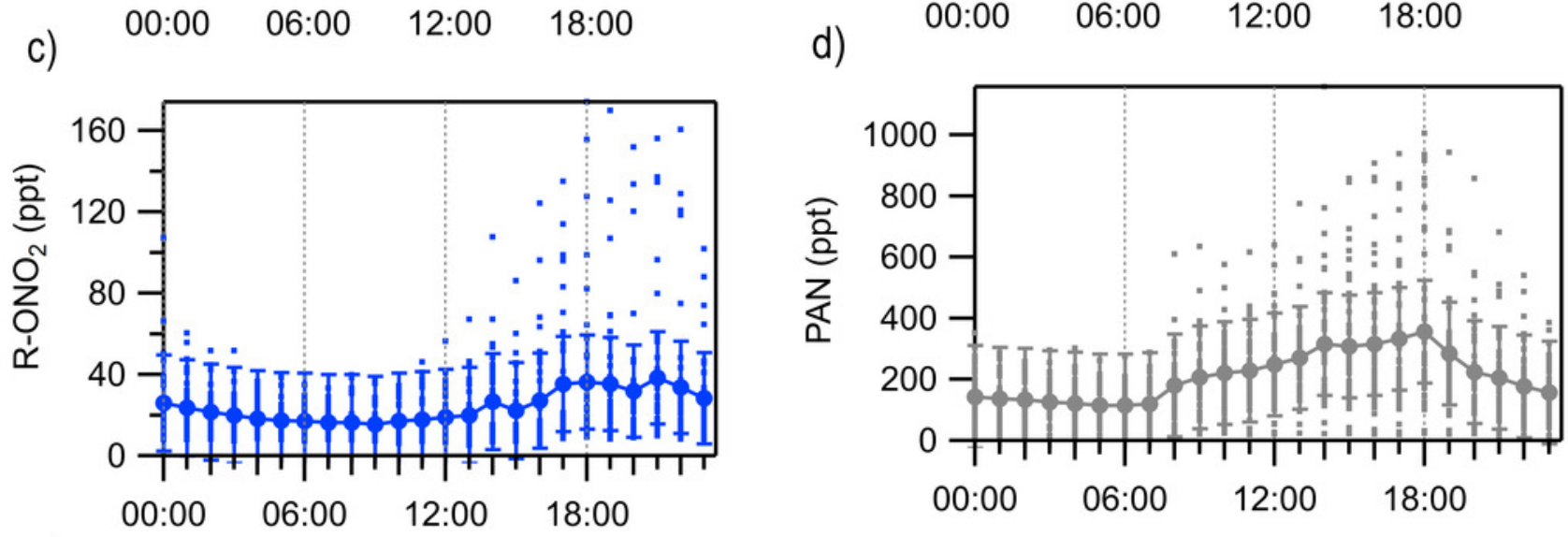

e)
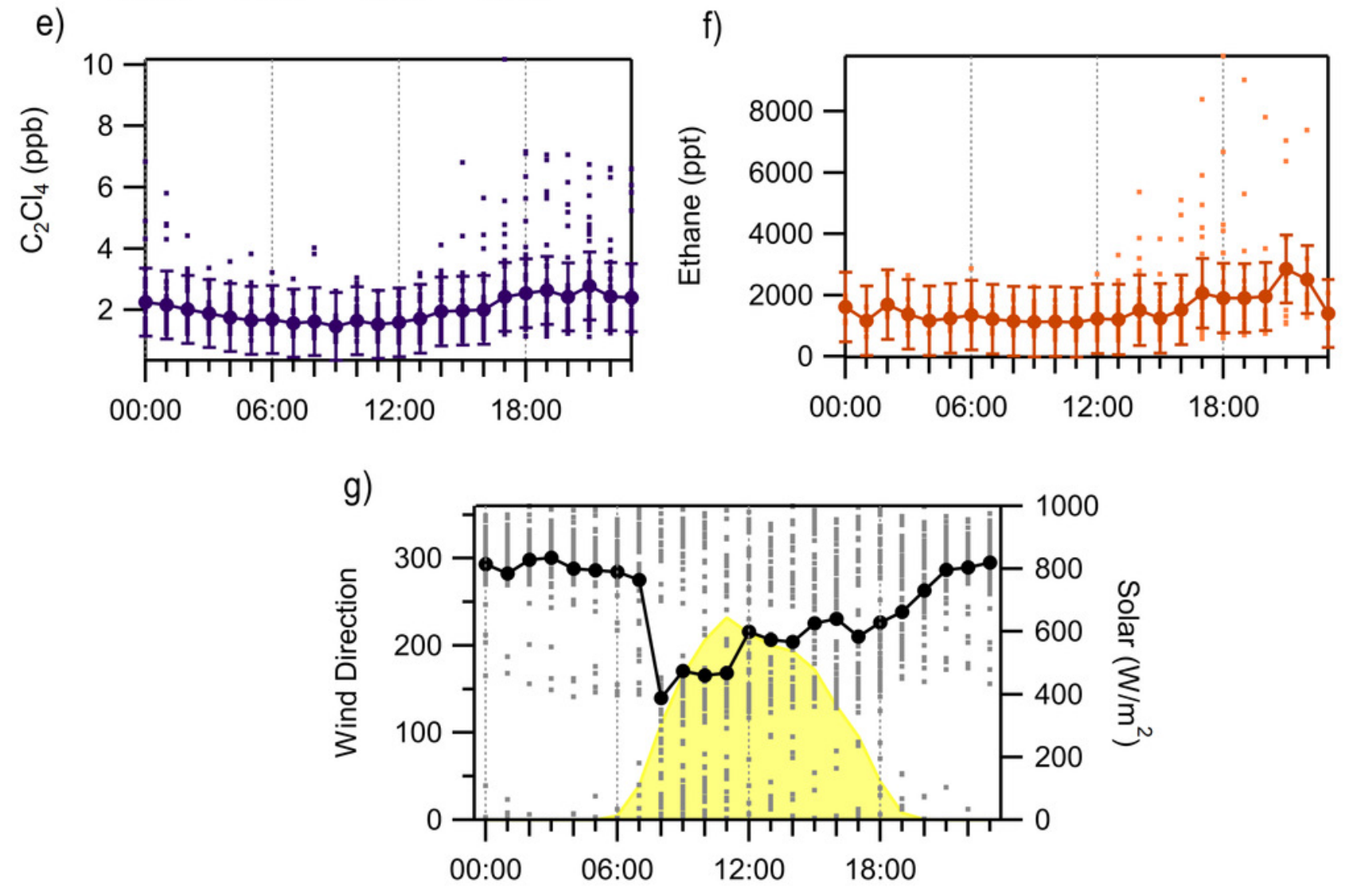


\section{Figure 5}

Atmospheric reactive nitrogen budget at ROMO for July 16-August 312014.

Concentrations were averaged over the study period and the average total reactive nitrogen concentration was $1.24 \mathrm{ppb}$. Not included in this assessment are some basic, gas-phase reactive nitrogen species such as amines and acetonitrile.

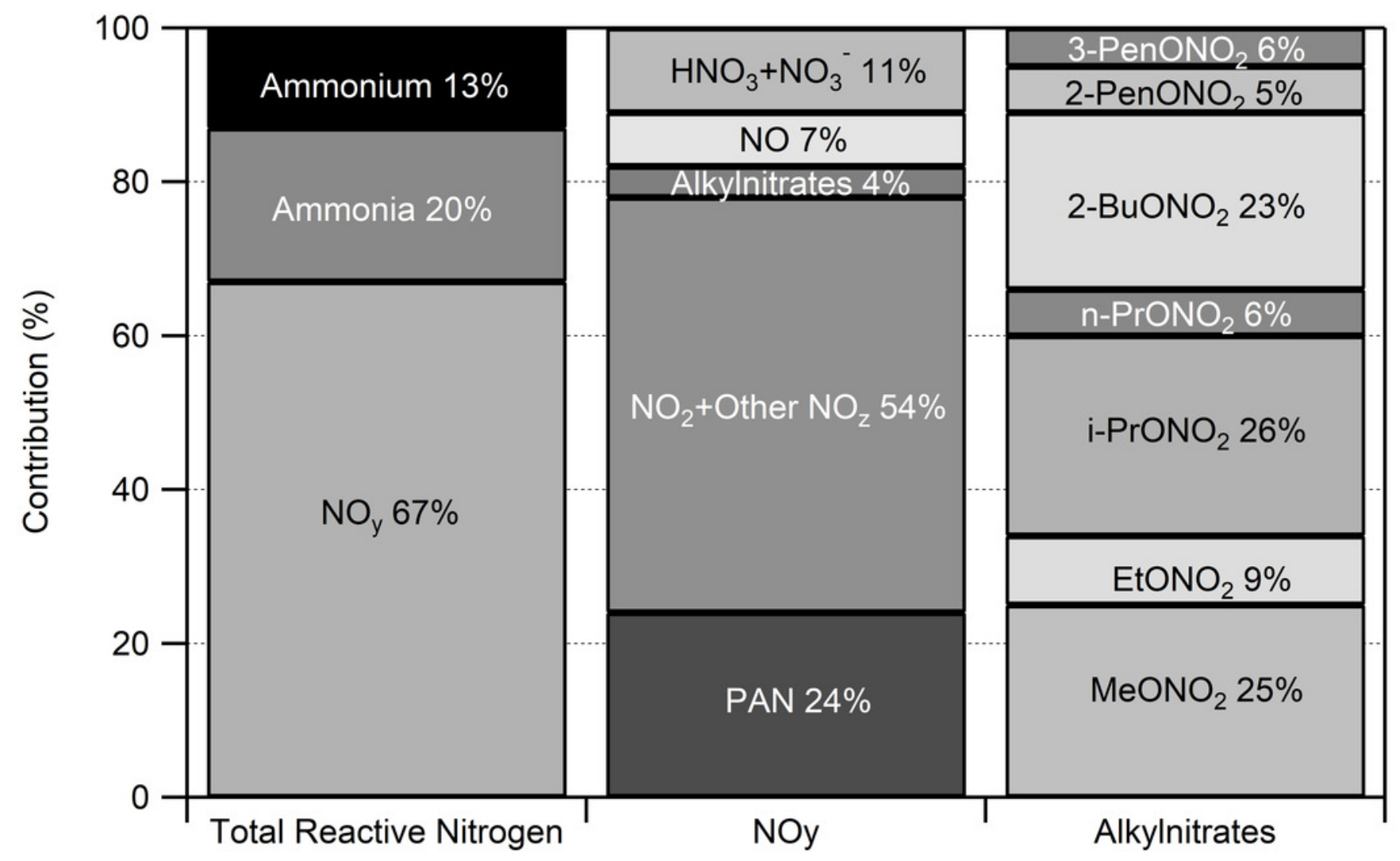




\section{Figure 6}

Relationship of methyl nitrate and other alkyl nitrates to ethyl nitrate.

a) i-propyl, n-propyl, and 2-butyl nitrate shown with ethyl nitrate and b) the relationship

between methyl and ethyl nitrate colored by mixing ratios of $\mathrm{CHBr}_{3}$ (ppt), a marine air mass

tracer highlighting the two sources of methyl nitrate at ROMO. 

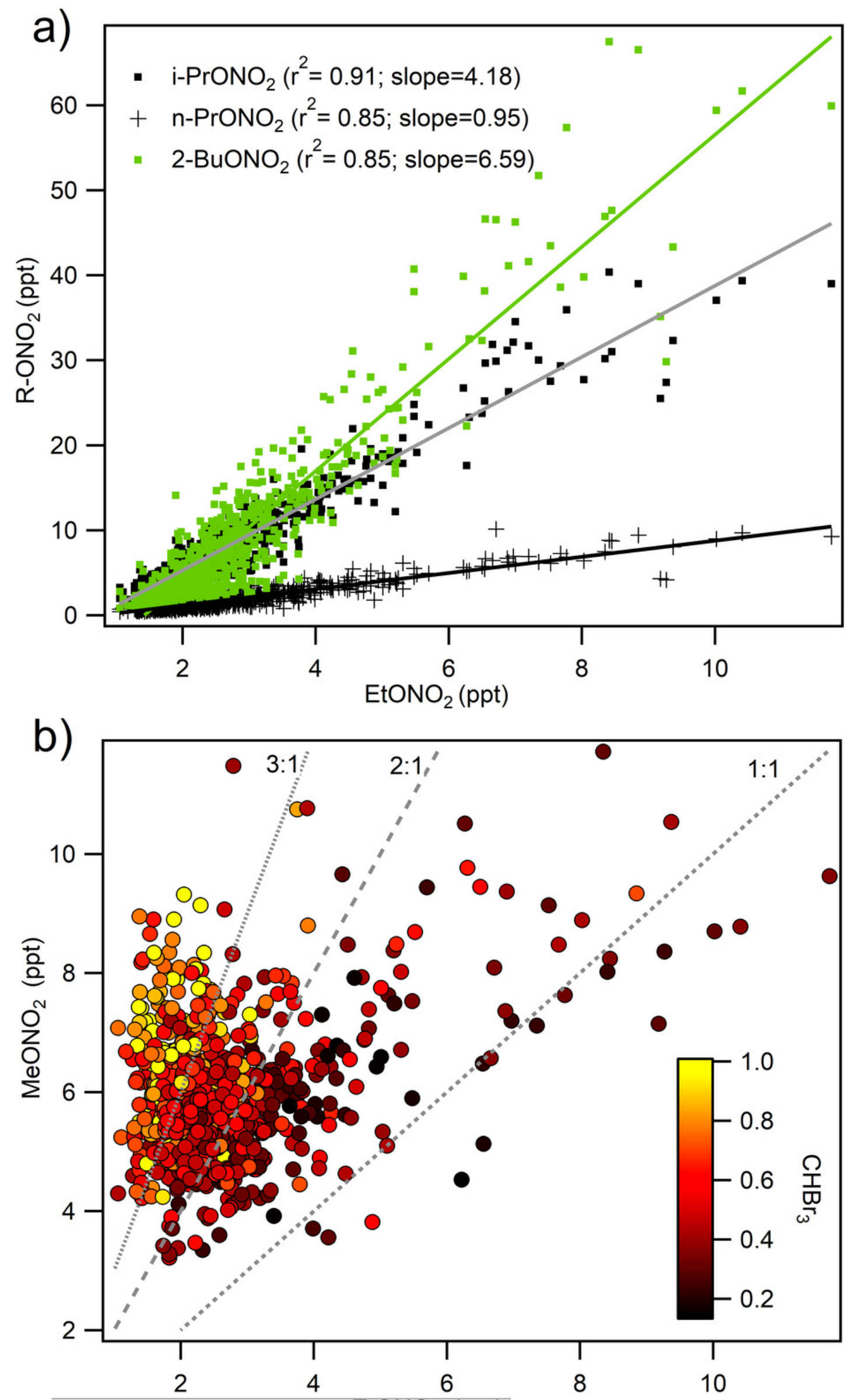


\section{Figure 7}

Contributions of the (a) various reactive nitrogen species measured to total nitrogen deposition and (b) breakdown of dry deposition.

\section{$\mathrm{R}-\mathrm{ONO}_{2}$}

a)

Total Nitrogen Deposition July 16-August 31

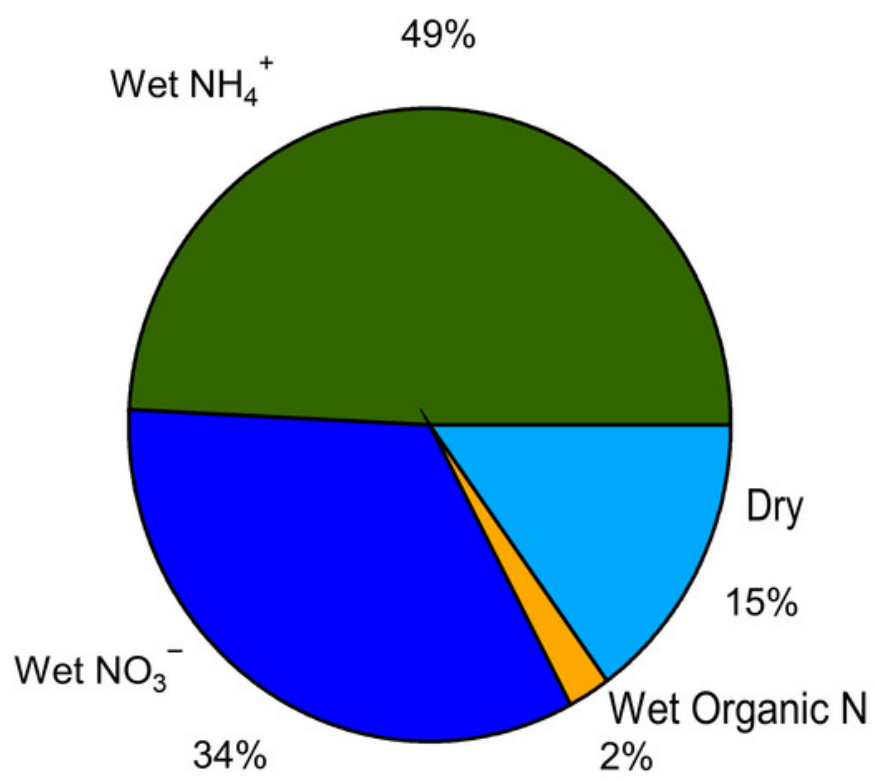

b)

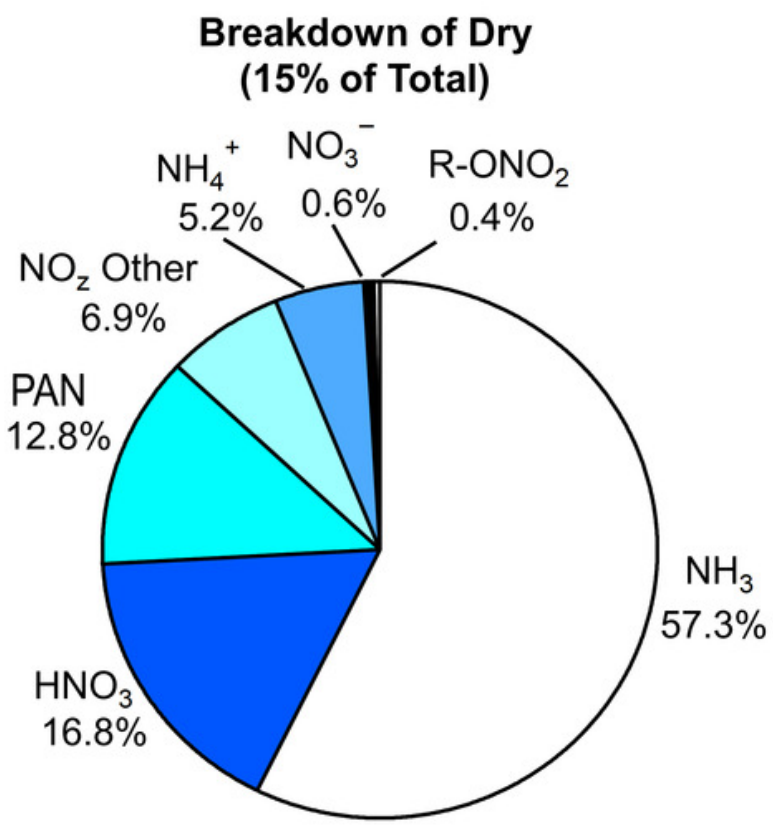




\section{Figure 8}

Relationships of the ratio of $\mathrm{i}$-butane to $\mathrm{n}$-butane to various species to separate the influence of Denver (solid) and the agriculture/oil and gas region (dotted) in the Front Range.

The i-butane to n-butane ratio and its relationship to (a) ethane, (b) $\mathrm{C}_{2} \mathrm{Cl}_{4}$, (c) $\mathrm{NH}_{3}$, (d) $\mathrm{NO}_{\mathrm{y}}$, (e) alkynitrates, (f) PAN are shown. 
a)

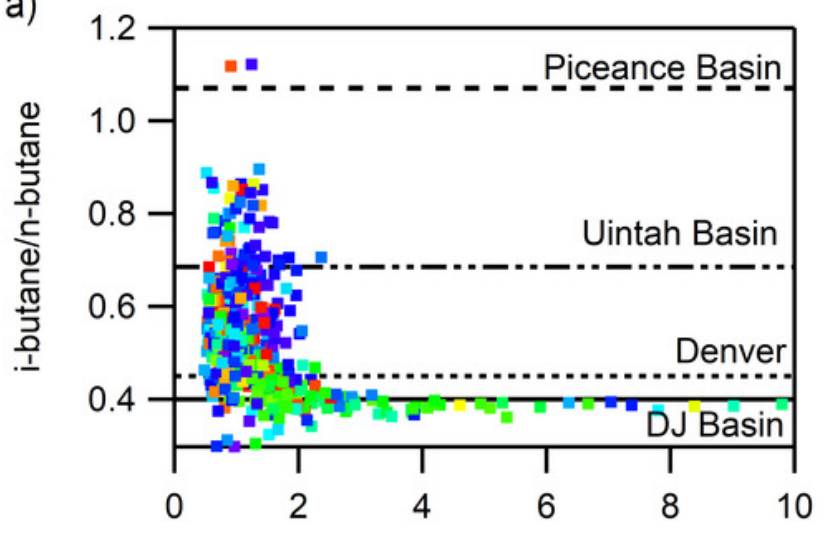

c)

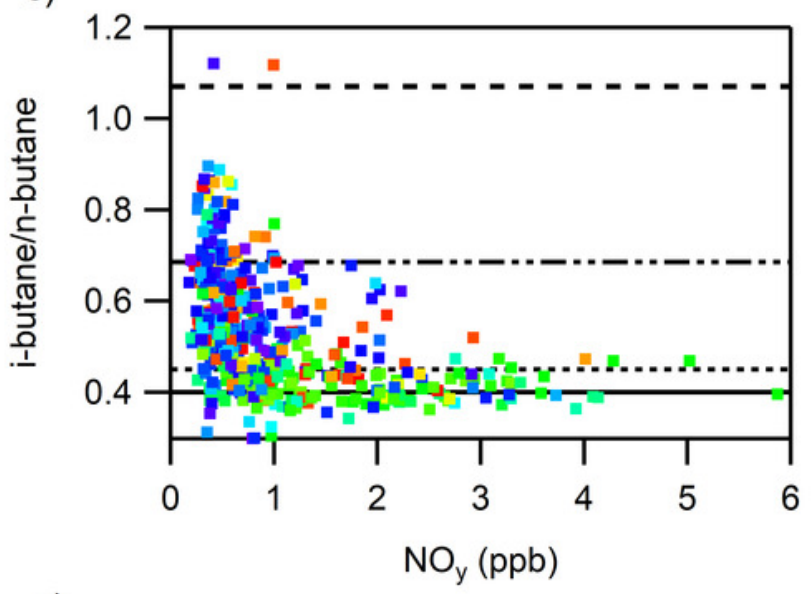

e)

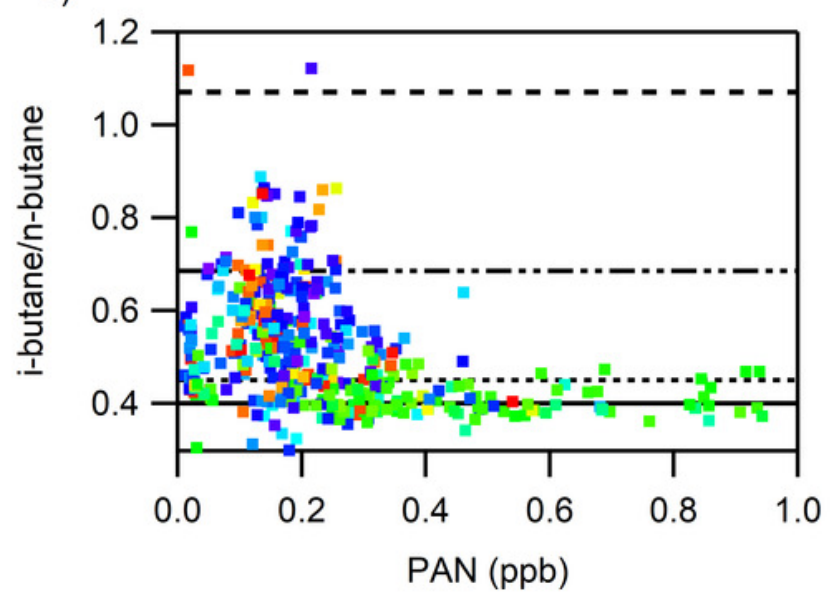

b)

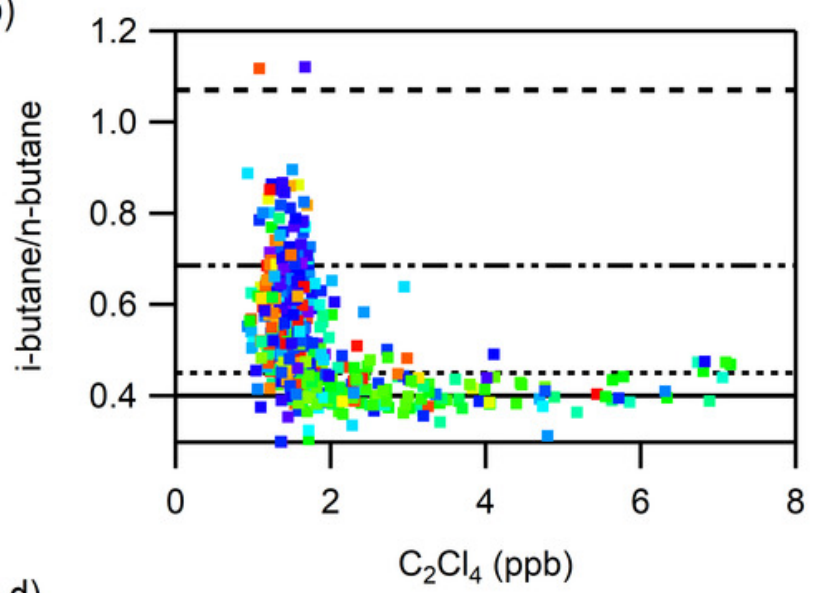

d)

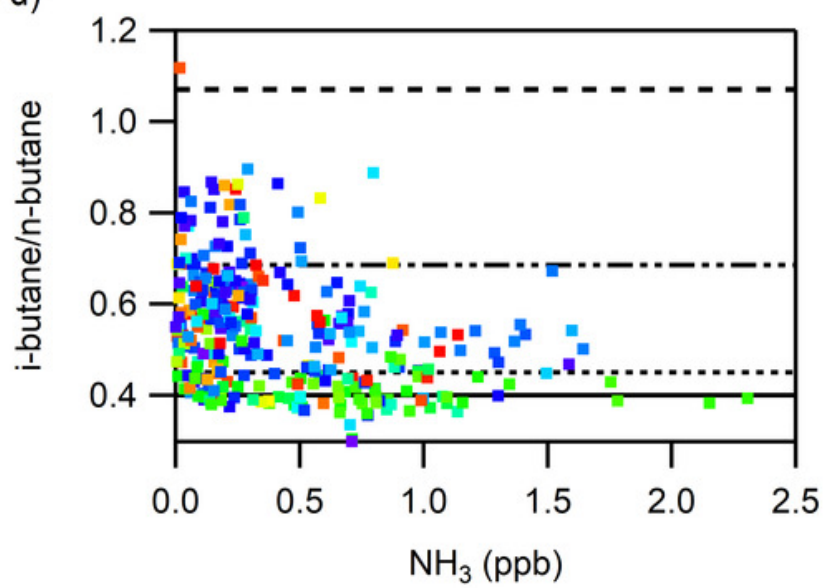

f)

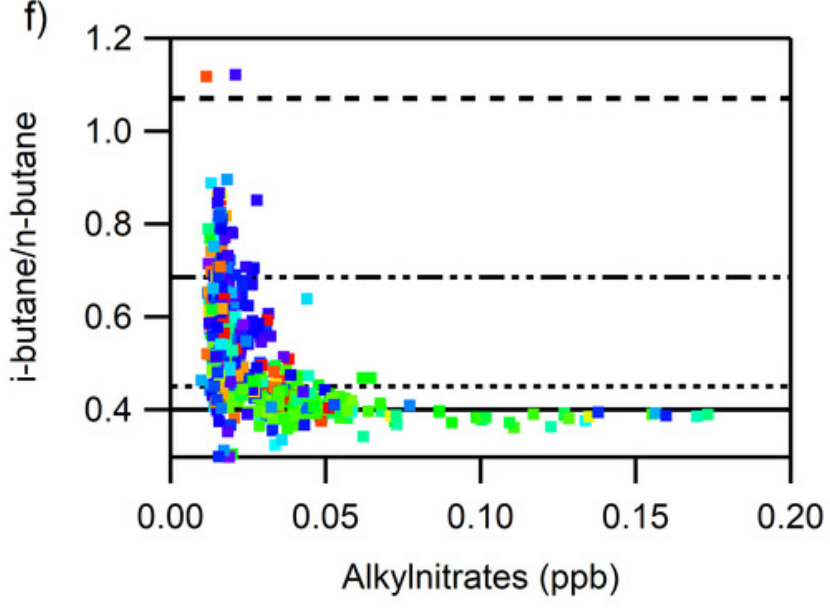

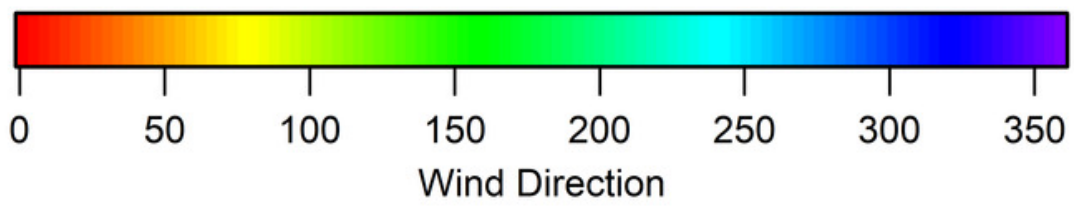


Figure 9

Relationship between reactive nitrogen species and $\mathrm{CHBr}_{3}$ colored by $\mathrm{MeONO}_{2} / \mathrm{EtONO}_{2}$

All points with a ratio greater than 3 are red.

a)

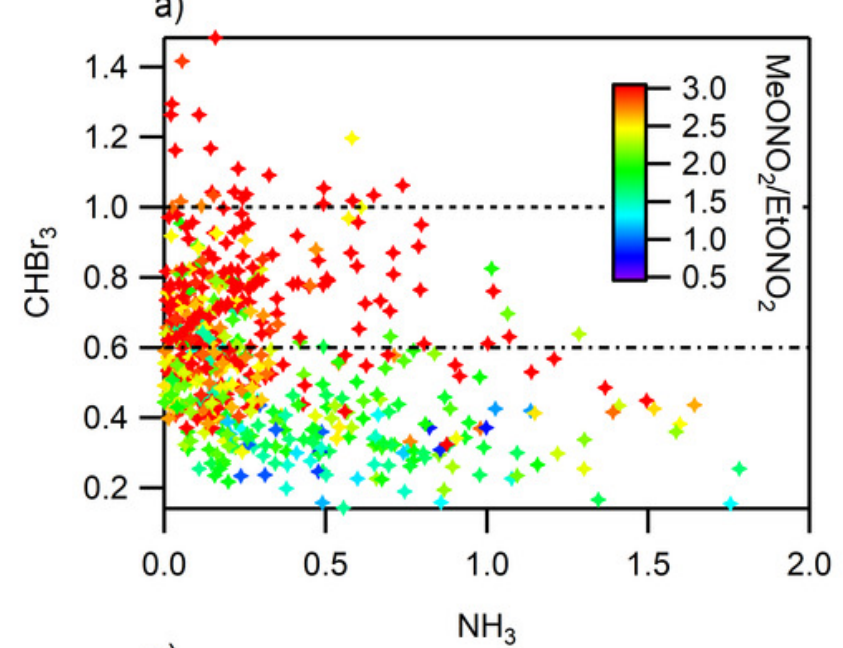

c)

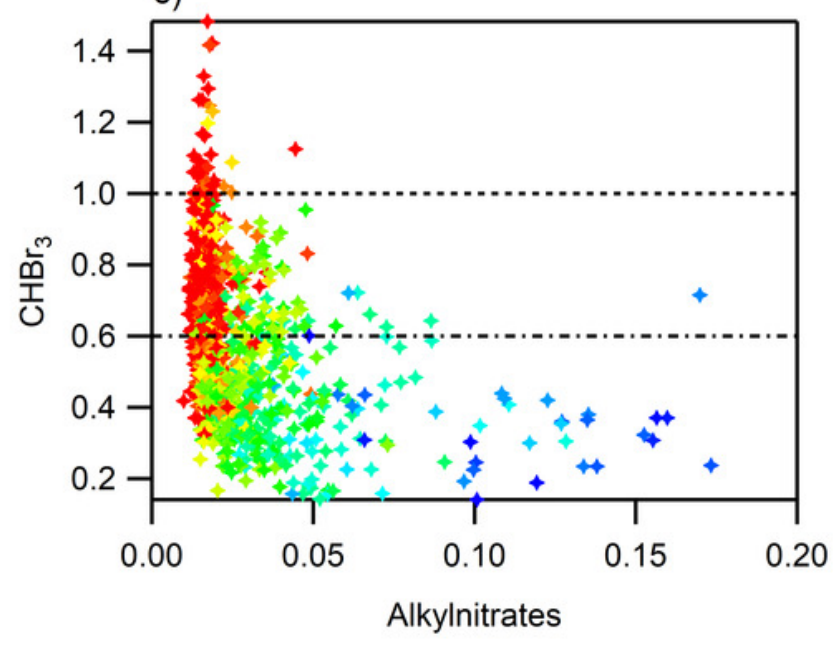

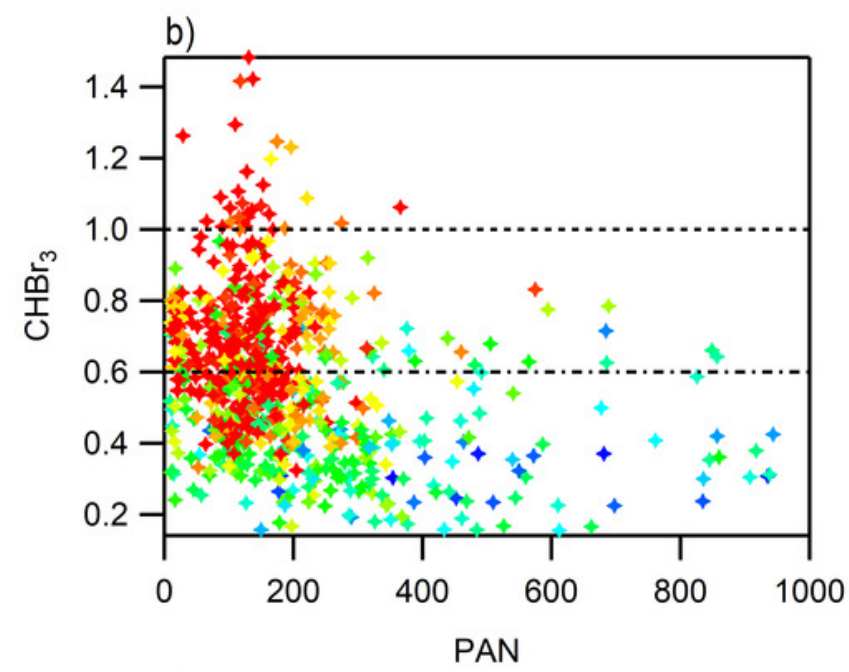

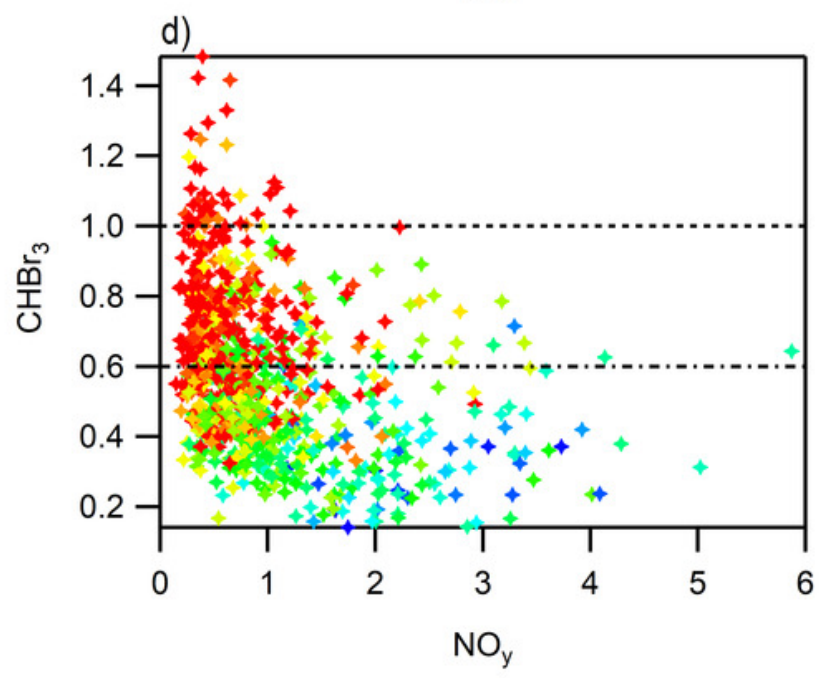




\section{Table $\mathbf{1}$ (on next page)}

July to August average reactive nitrogen concentrations (ppb).

Also included are the $\mathrm{NH}_{3}$ and $\mathrm{NH}_{4}{ }^{+}$fraction for the total oxidized and reduced nitrogen for multiple years of measurements made at RMNP. The FRAPPÉ study year is highlighted in bold for ease of comparison. 
1 Table 1. July to August average reactive nitrogen concentrations (ppb) and the $\mathrm{NH}_{3}$ and

$2 \mathrm{NH}_{4}{ }^{+}$fraction for the total oxidized and reduced nitrogen for multiple years of

3 measurements made at RMNP. The FRAPPÉ study year is highlighted in bold for ease of 4 comparison.

5

\begin{tabular}{cccccccc}
\hline & & & & & $\mathrm{NH}_{4}{ }^{+}$ & $\mathrm{NH}_{3}$ \\
fraction & fraction \\
\hline 2009 & 0.47 & 0.37 & 0.10 & 0.07 & 1.74 & $14 \%$ & $18 \%$ \\
2010 & 0.38 & 0.32 & 0.09 & 0.05 & 1.21 & $17 \%$ & $20 \%$ \\
$\mathbf{2 0 1 4}$ & $\mathbf{0 . 3 4}$ & $\mathbf{0 . 2 0}$ & $\mathbf{0 . 0 6}$ & $\mathbf{0 . 0 3}$ & $\mathbf{1 . 0 5}$ & $\mathbf{1 2 \%}$ & $\mathbf{2 1 \%}$ \\
2015 & 0.43 & 0.21 & 0.10 & 0.04 & 1.36 & $11 \%$ & $22 \%$ \\
2016 & 0.58 & 0.25 & 0.07 & 0.03 & 1.22 & $12 \%$ & $28 \%$ \\
\hline
\end{tabular}

6

7 


\section{Table 2 (on next page)}

Summary of precipitation for July-September for the intensive study years in ROMO.

Wet and dry nitrogen deposition are also included for comparison. 
1 Table 2. Summary of precipitation for July-September for the intensive study years in 2 ROMO. Wet and dry nitrogen deposition are also included for comparison. 3

\begin{tabular}{c|ccc|c|c|c} 
Year & $\begin{array}{c}\text { During } \\
\text { Upslope } \\
(\mathrm{mm})\end{array}$ & $\begin{array}{c}\text { Total } 7 / 1- \\
9 / 30\end{array}$ & $\begin{array}{c}\text { Fraction } \\
\text { During } \\
\text { Upslope }\end{array}$ & $\begin{array}{c}\text { Fraction } \\
\text { of time } \\
\text { flow } \\
\text { upslope }\end{array}$ & $\begin{array}{c}\text { Wet N } \\
\text { Deposition } \\
\text { July - Oct } \\
(\mathrm{kg} \mathrm{N} / \mathrm{ha})\end{array}$ & $\begin{array}{c}{ }^{\ddagger} \text { Estimated Dry } \\
\mathrm{NH}_{3}, \mathrm{HNO}_{3}, \\
\mathrm{NH}_{4}^{+}, \mathrm{NO}_{-} \\
\text {Deposition } \\
\text { (kg N/ha) }\end{array}$ \\
\hline 2009 & 32.6 & 102 & $33 \%$ & $33 \%$ & 1.24 & 0.38 \\
$2010^{*}$ & 39.9 & 170.9 & $26 \%$ & $23 \%$ & 0.82 & 0.25 \\
$2014^{+}$ & 62.8 & 221.8 & $32 \%$ & $37 \%$ & 1.37 & 0.21 \\
2015 & 17.1 & 108.1 & $18 \%$ & $25 \%$ & 0.72 & 0.28 \\
2016 & 23.3 & 60.4 & $30 \%$ & $27 \%$ & 0.85 & 0.35
\end{tabular}

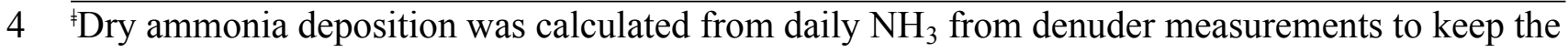
5 calculation consistent across all study years. *July 1 - Sept 20, ${ }^{+}$July 7 - Sept 30 


\section{Table 3(on next page)}

Correlation $\left(\mathrm{R}^{2}\right)$ between the tracer species (ethane, $\mathrm{C}_{2} \mathrm{Cl}_{4}$ ) and the various $\mathrm{RN}$ species (ppb). 
1 Table 3. Correlation $\left(\mathbf{R}^{2}\right)$ between the tracer species (ethane, $\left.\mathbf{C}_{2} \mathbf{C l}_{4}\right)$ and the various $\mathbf{R N}$ 2 species (ppb).

3

\begin{tabular}{|c|c|c|}
\hline & Ethane $\left(\mathrm{R}^{2}\right)$ & $\mathrm{C}_{2} \mathrm{Cl}_{4}\left(\mathrm{R}^{2}\right)$ \\
\hline $\mathrm{NH}_{3}$ & 0.01 & 0.01 \\
\hline $\mathrm{NO}_{\mathrm{y}}$ & 0.33 & 0.59 \\
\hline $\mathrm{NO}$ & 0.003 & $2 \mathrm{E}-4$ \\
\hline PAN & 0.27 & 0.35 \\
\hline $\mathrm{MeONO}_{2}$ & 0.05 & 0.05 \\
\hline $\mathrm{EtONO}_{2}$ & 0.68 & 0.42 \\
\hline $\mathrm{i}-\mathrm{PrONO}_{2}$ & 0.79 & 0.47 \\
\hline $2-\mathrm{BuONO}_{2}$ & 0.85 & 0.44 \\
\hline 2-PenONO 2 & 0.87 & 0.42 \\
\hline 3-PenONO ${ }_{2}$ & 0.86 & 0.44 \\
\hline
\end{tabular}

4 